\title{
学会 賞各種植物測粉の検索と特性
}

（鹿児島県経済連・食品総合研究所）藤本滋生

緑葉植物の多くは、合成した澱粉の一部を種子や根あるいは茎などの組織中に眝えている。 植物の種類により澱粉の眝蔵量には著しい差があるだけでなく、澱粉の性質もそれぞれ異なっ ていることが知られている。「どの植物がどのような性質の汼粉を持っているのか」あるいは 「溊粉の性質の違いには、どれくらいの範囲があるのか」という課題は、溊粉の本質を究める ための出発点でもあろう。

筆者らはまず文献を調查し、つづいて溊粉の存在が記録されている植物を手はじめに、わが 国に自生する多数の植物から澱粉を調製した。

地上澱粉としては種子の澱粉がもっとも多く、なかでも量的にはブナ科（どんぐり類）、マ メ科（豆類）、およびイネ科（穀類）が目だっている。一方地下部では、葉が肥大した組織で ある鳞茎に眝えるのがユリ科とヒガンバナ科の特徴といえ、茎の部分が肥大した球茎はアヤメ 科に多い。地下の茎が不規則に肥大したものは塊茎と称され、サトイモ科やバショウ科に多い が、ガマ科やカヤツリグサ科にもみられる。地下を走っている茎である根茎に溊粉を眝える植 物も多い。とくにショウガ科やカンナ科ではこの根茎が著しく肥大している。根に眝えるもの、 そのためとくに肥大してサツマイモのように塊根となっているものは双子楧類全体に分布して いる。このように溊粉を多く眝蔵する植物は分類系上にさほど偏りなく、“目”のなかでは約 4 割、“科では約 2 割にみられた。

調製した溊粉について、組成や粒径、基本的特性などを一貫した手法で測定し、比較した。 （1）このうち地上澱粉：地下溊粉が $1 ： 2$ の割合になる 72 種の澱粉につき、(1)平均粒径、 (2)アミロース含量、(3)糊の粘度、(4)糊化温度の 4 項目を選び、その分布や平均值を求めた。涮 粉粒の大きさは $1 \mu \mathrm{m}$ から $100 \mu \mathrm{m}$ を越えるものまであるが、平均粒径の平均値は 12.2 $\mu \mathrm{m}$ であった。アミロース含量の分布はほぼ $20 \sim 30 \% に$ 集中していた。また糊化温度につ

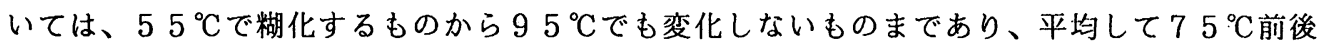
にピークがあった。アミログラム上の最高粘度のバラツキは非常に大きく、0〜 $1000 \mathrm{~B} \mathrm{U}$ までの間でピークらしきものはなかった。

(2)これら 4 項目間の相関関係をみると、糊化温度と最高粘度の負の相関がもっとも高い。 つぎに平均粒径と最高粘度、アミロース含量と糊化温度が続いている。

（3）以上の結果を参考にしてこれら 4 項目による十字形のスケールを想定し、各溊粉の特性

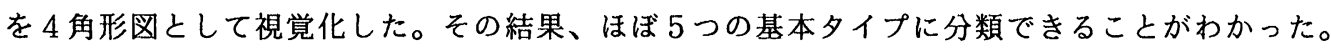

（4）分類上の近縁種の溊粉はやはり似ているものが多く、なかにはほとんど区別できない場 合もある。一般に穀類は互いによく似ており、ショウガ科、カンナ科、およびバショウ科では 科にまたがって共通した点が多い。かし豆類澱粉はバラエティに富んでいた。一方、思いがけ ない植物同志がよく似た澱粉をもっている場合もいくつかあった。

（5）植物の分類系はそのまま植物の進化を示すものではなく、現存の植物を進化の順に並べ ることもできないが、少なくとも系統樹の図からみれば、シダ植物〜裸子植物〜被子植物の順 に古い形質を残しているものと思われる。しかし溊粉の性質に関しては、いまのところこの 3 者の間には有意差を認めることはできなかった。これらの問題を諭ずるには、試料数や分析項 目などが不足しているのかもしれないしあるいは別の指標があるのかもしれない。 


\section{学会賞 WHEAT STARCH; PROPERTIES AND MODIFICATION}

(Department of Grain Science and Industry, Kansas State University) Paul A. Seib

Maize, cassava, potato and wheat are the principal sources of commercial starches. Wheat starch is isolated in modern plants starting from a flour-water slurry rather than an elastic dough. Among the four commercial starches, normal maize and wheat starches resemble each other the most, yet those two cereal starch differ in color, granule size, composition, gelatinization, pasting, gelling, and retrogradation. Even between classes of wheat, differences exist in their starches. Wheat starch (94\% yield) from four classes (four cultivars each at four locations for 2 years) increased in amylose and lysophospholipids in the order soft red winter $<$ hard red winter $<$ hard red spring $<$ durum, whereas swelling power $\left(85^{\circ} \mathrm{C}\right)$ was in reverse order. Elevated grain-filling temperature $\left(40^{\circ} \mathrm{C}\right.$ versus $15^{\circ} \mathrm{C}$ over a 5 -hour daylight period in a growth chamber) reduced starch accumulation, granule size, and number of B-granules. Starch lipids were markedly increased and amylose slightly increased as grain-filling temperature increased, which resulted in reduced starch swelling $\left(85^{\circ} \mathrm{C}\right)$. Starches from most wheats grown at $40^{\circ} \mathrm{C}$ had an increased proportion of unit chains with a degree of polymerization (DP) between 10-16 and a reduced proportion of unit chains with DP 17-21. Starches from wheats grown at $25^{\circ} \mathrm{C}$ had the highest proportion of unit chains with DP 16-24, which appeared to explain its increased extent of retrogradation compared to the sample grown at $40^{\circ} \mathrm{C}$. The properties of wheat starch have been modified by classical methods of acetylation, hydroxypropylation, phosphorylation, and cross-linking. Hydroxypropylated wheat starch was found to perform well in several Japanese foods. Granular cold-water soluble wheat starch is readily prepared by heating a mixture of wheat starch/water/1,2-propanediol $(1 / 1.5 / 4.5, w / w / w)$ to $113^{\circ} \mathrm{C}$ followed by solvent exchange with ethanol. 
特別講演多糖の化学と開発の現状について

(福山大学工学部生物工学科) 山本武彦

多糖は、その種類、量は別として、蛋白、核酸（ティコィン酸のアナローグの一っとす みなされる。）ととすに生体に存在する高分子成分である。多糖の多は定義し難いが、そ れはエネルギー源として、構造成分として、或は機能物質として細胞、組織に存在する。 存在㗐乃至生産量としては、セルロース、噼粉などの木モ多糖が压倒的に多いが、種類と してはへテロ多糖や糖蛋白などの複合多糖の方が多い。

近代化学は溊粉、セルロ一スについては勿論、種々植物起源のガム質多糖や海藻起源の 種々多糖についての化学的研究や利用開発を行った。セルロースを例外としてての成果の 多くは、食品或は食品改質風としての分野に片寄っている。最近は抗癌乃至抗発癌作用や 栄䬭調整作用の研究と応用が注目されている。

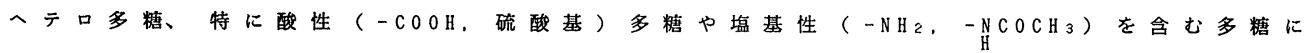
特徽ある物性と機能を示すすのが多い。ビアルロン酸は、蛋白さらにこれに他の多糖を結 合して领骨の成分となっている一方、殆ど遊雖の状態で眼のガラス質や関節の滑液に存在 する。人体にみられる他の多糖例えばへパリン、コンドロイチン硫酸には局在性があって 構造上或は機能上の役割がみられる。勿論、植物多糖もこれの生成体にとっては生物学的 意義があるだろうが、この種の研究は少ないように思われる。サイリュゥム(Psylium seed) ガムやグアー（ｇuar）ガムは化学構造が殆ど不明であった時代に沈溊剂として利用 された。他方、大腸菌の或る株はシアル酸のポリマ-（ｃ０１０ｎｉｃａcid）を生成すること判 つて激く 20 年後にそれの実用化が行われている。

多糖の構造決定方法す大方確立した。新しい多糖を探索するととるに、既知多糖の權造 と物性の関係、部分分解物の生理 ·生化学的作用の研究る推進すべきと考元られる。 
Aa-1 イネ突然変異体の肧乳溊粉の特性

(福山大・工)

○朝岡正子、廣橋靖助、大柴正之、重松利典、井ノ内直良、不破英次

[目的]イネ肧乳澱粉の特性を変える突然変異体は澱粉の生合成経路の解明、新品種の育 種の材料として有用である。本研究では日本型水稲を突然変異誘発剤で処理することによ り作出されたsugary (sug)、dull(du)、floury (flo)、amylose extender(ae) shrunken $(s h r) 、 g i a n t e m b r y o(g e)$ 突然変異体胚乳より澱粉を調製し、その特性を調へた。

[方法] 試料として上記変異体 18 試料の精白米より冷アルカリ浸漬法にて澱粉試料を調 製し、ヨウ素・涮粉複合体吸収曲線、イソアミラーゼ枝切り後のゲルクロマトグラフィー、 示差走査熱量測定（DSC）を行った。また、精白米粉の粘度特性をラピッドビスコアナラ イザー（RVA）にて調へた。

[結果] ヨウ素・澱粉複合体吸収曲線より求めたsug（EM 5)、flo（研系2047）、shr（研 系2088）、ge（探系2030）の最大吸収波長（ $\lambda$ max）、Bluevalue（680nmにおける吸光 度）は一般的な日本型水稲胚乳のものと大きな違いはなかった。しかし、 $a e$ (研系2064) のものはBlue valueが0.32、0.37と高く、またduのものは $\lambda$ maxが545〜 567n m、Blue valueが $0.13 \sim 0.23$ であった。イソアミラーゼ枝切り後のゲルクロマトグラフィーにより 求めた澱粉のアミロース含量は $d u$ 以外のものは $15 \sim 18 \%$ あっったのに対し、 $d u$ のものは 7〜 $18 \%$ と広い分布を示した。DSCによる澱粉粒の糊化開始温度はEM 5 ( sug)の $55^{\circ} \mathrm{C}$ から研 系2064（ae) の $75^{\circ} \mathrm{C}$ の範囲の間であった。10\%精白米粉榡濁液のRVAによる粘度測定の結 果、EM5 (sug) 、研系2088 (shr) の最高粘度が低い傾向にあり、duのものの最高粘度が 高くセットバックが小さかった。

Aa-2 9 品種のクワイ搌粉の二,三の性質について

（武庫川女子大・家政，*府立城山高校，**福山大・工）

○杉本温美，白井裕紀子，若林由起，*谷本忠芳，**不破英次

〔目的〕クワイ澱粉の性犋ならびに生育中の変化については既に報告じた。鈴木らうもクワ イ澱粉の構造および機能的性啠の特徵を明らかにしている。さらに今回，品種の違いによ るクワイ澱粉の特徵を明らかにするため，9品種のクワイについて澱粉の性質を調べた。 〔方法〕試料としたクワイは，1991年大阪府立園芸高校で栽培した白クワイ(A)，青 クワイ (B)，吹田クワイ(C)とこれら3種のかけあわせによってできた白×青 (D)，白×吹 田 (E)，青X白 (F)，青 $\times$ 吹田 (G)，青X青 (H)，吹田 $\times$ 吹田 (I) の合計 9 種類である。澱粉

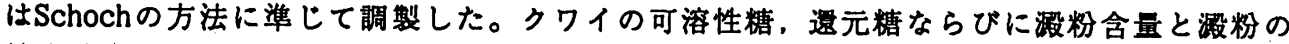
粒度分布，酳素分解，分解残さ澱粉のS E M 観察、溶解度、膨潤度，電流滴定によるアミ ロース含量、ヨード吸収曲線、示差熱分析（DSC），X線回折は常法に従った。

〔結果〕クワイの可溶性糖は $4.3 \sim 6.2 \%$ ，還元糖0.2〜0.4\%で還元糖はほとんど含まれて いなかった。澱粉含量は15.9〜24.9\%で (E)が一番少なく，(I)が一番多かった。粒度分布

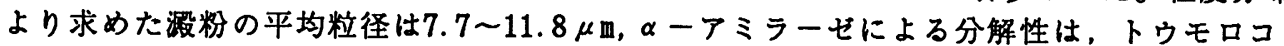
シ澱粉粒を 100 とした場合，3時間反応で58.7〜81\%，24時間反応で81.2〜94.4\%とクワイ

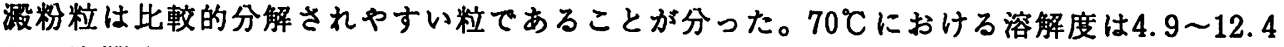

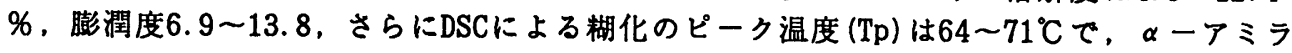

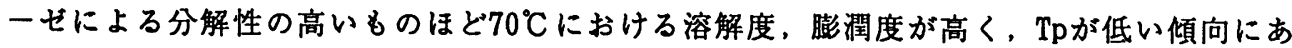
った。みかけのアミロース含量は28〜30\%で品種による差があまりみられなかった。 X 線 回折図は 9 品種とも，A図形であった。

1) 杉本ら：栄盖・食糧学会誌, $37,465 \sim 473(1984)$ 2) 杉本ら：潵粉科学, $35,11 \sim 18$ (1988) 3) A. Suzuki et al:Denpun Kagaku, 40, $41 \sim 48$ (1993) 
Aa-3 市販サッマイモ澱粉（わらび䬷粉）の性貿に及ぼす粒子径と無機貿の影辢 （広島大・教育）井川佳子

\{目的\} わらび餅粉として市販されているサッマイモ澱粉は、澱粉粒の性貿やゲルの

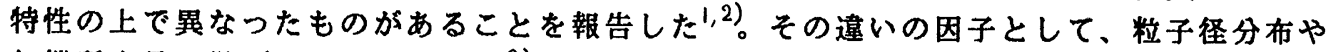
無機筫含量を举げることができる ${ }^{2)}$ 。今回は澱粉の性質とこれらの点との関孫を明らかに することを目的として、以下の実験を行なった。

\{方法\} 3 種のサッマイモ激粉（A，B，C）を水中での沈降によって、小粒の多い区 分 ( $\mathrm{AS}, \mathrm{BS}, \mathrm{CS})$ と大粒の多い区分（AL，BL，CL）に分別した。また、サッマイモ澼粉製 造工場より精製途中の涮粉を入手し、一部分は水洗のみで、一部分は石灰処理を行なって、 実鮯室で精製した。乾燥は自然乾燥法とした。

各溊粉の性質を、膨潤度と熟糊化過程の粘度の测定、示差走查熱量分析を行なって比較 した。また、おらび餅調製時の加熱方法をモデル化して、13、5-16\%濃度のゲルを作製し、 レオロメータマックス（アイテクク）を用いてかたさや凝集性を測定し、同時に老化性等を調へた。

\{結果\}大粒の多い試料 $\mathrm{AL}, \mathrm{BL}, \mathrm{CL}$ は小粒の多い試料に比へ、膨潤しやすく、最高 粘度が高かった。また、AL，BL，CL のゲルはかたさの值が小さくなった。

石灰処理を行なった澱粉の陽イオンはほとんどがCaであり、水洗処理のみの澱粉はK と Caがほぼ同量含まれていた。しかし、この 2 試料間で膨潤度や粘度の差は小さく、ゲルの 物性や老化性にも大きな違いは見られなかった。

1) 井川佳子；調理科学 26 No.2 印刷中

2) 井川佳子; 調理科学 投稿中

$\mathrm{Aa}-4$ 古糊の研究

山田哲也、○中野勲、磯部正樹、寺西克倫、久松 員、“岡岩太郎 (三重大.農化) (“岡壘光堂)

〔目的〕日本画の表装に用いられる古糊（ふるのり）は、小麦腶粉の市販洗濯糊を冬期に弱火で丸一日 者てから瓶容器に入れ、和紙で蓋をし、10年以上保存したものである。この糊について研究がいくつ

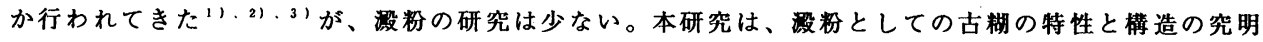
を目的として行った。

〔方法〕古糊を凍結乾燥又はメタノール沈殿処理して試料とした。その試料をX線回折に供した。次に、 $\beta$-アミロリシスの測定を行った。又、過塩素酸溶解後、イソアミラーゼ処理したものと処理を行って いないものを各種ゲルクロマトグラフィー(Toyopearl HW-75F,65F,50SF)に供し、同時にヨウ素筑 粉反応の $\lambda \max , \varepsilon_{680}$ を測定した。又、䣼素感受性を測定した。BAP法を用いて古糊の糊化度を算出し た。なお、これらの結果をすべて小麦腶粉の結果と比較した。

〔結果〕 X 線回折は、老化澱粉に見られるB型図形に類似していた。小麦澱粉と較へ入 $\mathrm{max}$ は変わらな

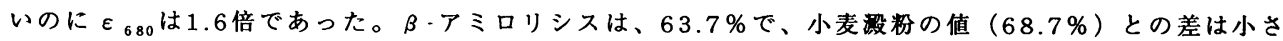
かった。GPCパターン（75F）ではアミロペクチン（Ap）、アミロース（Am）の溶出位置にピークは 全く見られず、さらに低分子側で一つの鋭いピークが見られた。GPCパターン（65F）は、この傾向が より鮮明となった。イソアミラーゼ処理後のGPCパターン（50SF）では、ボイド付近と平均重合度 45 付近、14付近の3つのピークが見られたが、通常の小麦渐粉のGPCパターンとはそのヒ・ークの割合が大 きく異なっていた。BAP法で得られた糊化度は、低い値を示した。これらの結果から、古糊は、冬期 の凍結と融解過程等によりApもAmも比較的狭い範囲の分子量のデキストリンに分解し、極端に老化 した構造のあることが示唆された。

1）槞沢孝一ら：農化、54（7）、551 553(1980)

2) 境沢孝一5: 防菌防微、9（4）、185 189(1981)

3) 潼沢孝一5: 中央大学理工学部紀要、29、317 333 (1986) 
Aa-5 大麦澱粉の全粒と大中小粒の構造

(鹿悓島大・生物資源化学 $\cdot *$ 連合農学研, $* *$ 鹿児島純心女子短大)

○竹田靖史, **竹田千重乃, *水上浩之, 槍作 進

[目的］大麦澱粉は小粒を特に多く含むのが特徵であり，全粒や分画した大小の粒の構造 や性質が調べられているが，アミロースとアミロペクチンに分別して構造を詳細に調べた 報告は見あたらない. 本研究では, 大麦澱粉(全粒)の構造の特徵を明らかにするとともに, 大中小の粒に分画して構造を精査した.

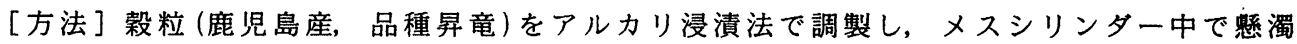
液を静置し，大粒 (2時間で沈澱する画分)，中粒 (2-20時間で沈澱する画分)と小粒 (20時間 で沈溊しない画分)に分画して構造を調べた. 各種分析方法は既報 ${ }^{1} に$ 準じた.

[結果] (1)大中小の粒の収率 (重量)は，それぞれ79，11，10\%で，平均粒径は20，7.5, $2.3 \mu \mathrm{m}$ であった. アミロース (AM) 含量は, 大中全粒が 24.7-25.4\%で小粒が $20.3 \%$ と低かっ

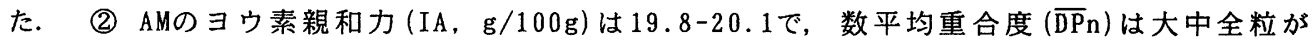
1570-1640で小粒は1900と僅かに大きいが, 重量平均重合度 (5540-5840)は類似した. 平均 鎖長は大中全粒が 295-330で小粒が 265, 平均鎖数は小粒 (7.2)が大中全粒 (4.9-5.6)より多

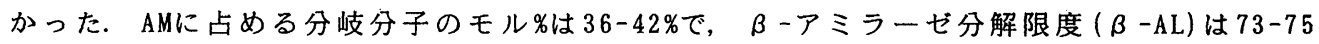
\%とほほ同じであった. (3)AMの $\beta$-アミラーゼ限界デキストリンでは, IAが18.6-18.9で, $\overline{\mathrm{DP}} \mathrm{n}$ は小粒 (1810) が大中全粒 (1440-1600)よりやや大きく, 平均鎖数は小粒 (16.5) が大中全 粒 (10.3-13.2) より多かった. (4)アミロペクチン (AP)では, IA (0.60-0.75), $\overline{\mathrm{DPn}}(25000-$ 27000), 平均鎖長 (18-19)と $\beta-A L(55-56 \%)$ は全ての粒でよく類似した. 以上の結果は, 大 麦溊粉 (全粒)は, 米やトウモロコシ (Normal種)と比べてAM含量が多く, AMとAPの分子が大

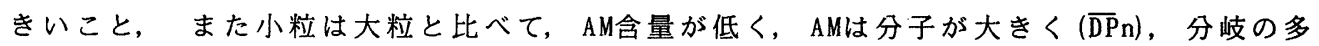
いことが特徵であることを示している. 1. 竹田靖史：澱粉科学, 年 (1993) 61-71.

\section{Aa-6 アミノ酸結合澱粉粒ハイブリッドの調製とその性質}

○楊 文紅、服部 誠、高橋幸資 (東京農工大・農)

[目的] 我々は、馬鈴薯澱粉にタンパク質を共有結合させた新規のハイブリッドを調製することにより、 澱粉の機能改変を試みている。これまでに、カルボキシメチル化した馬鈴薯搌粉 (CMS) と分離乳清 タンパク質をハイブリッド化し、糊化温度の著しい上昇、糊化時の膨潤の程度の限定化、溶解度の著し い低下、老化の抑制、低温における安定性の向上、乳清タンパク質中の主成分である $\beta$-ラクトグロブ リンの有するレチノール結合能の付与といった機能の改変に成功している。今回は、CMS にアミノ酸 を結合させた6種類のハイブリッドを調製し、その性質について検討した。

[方法] 水溶性カルボジイミド(1-ethyl-3-(3dimethylaminopropyl) carbodiimido hydrochloride; EDC) 溶液 $(1 \mathrm{~g} / 60 \mathrm{ml})$ に CMS $1 \mathrm{~g}$ を懸濁し、さらにアミノ酸(Gly, Leu, Glu, Lys, Cys あるいは Phe) $1 \mathrm{~g}$ を添加後、 $24^{\circ} \mathrm{C}$ で 5 時間反応させた。 $1 \mathrm{M}$ 酢酸 $3.6 \mathrm{ml}$ を加えて反応停止後、蒸留水により洗浄、 風乾乾燥してアミノ酸結合澱粉粒ハイブリッドを得た。得られたハイブリッドの性質について、DSC による熱安定性の解析、溶解度の測定、 $\alpha$-アミラーゼ被消化性の検討を行なった。

[結果・考察] アミノ酸とのハイブリッド化により、乳清夕ンパク質とハイブリッド化した場合と同様 に、糊化時の膨潤の程度は極めて限定され、また溶解度は著しく低くなった。DSCにより熱安定性の 解析を行なった結果、いずれのアミノ酸を用いてハイブリッド化した場合も、糊化温度はCMSより高 く $\left(4-17^{\circ} \mathrm{C}\right.$ 上昇 $) 、$ 熱安定性の向上が認められた。特に、疎水性アミノ酸を結合した場合に、熱安定性の 顕著な向上が認められた。ハイブリッドの $\alpha$ ーアミラーゼ被消化性については、加熱前はCMSと比べ非 常に高かったが、加熱後はCMSと比べ著しく低かった。 
Aa-7 パルス電流検出法(PAD) を用いた高性能陰イオン交換クロマトグラフィー （HPAEC）によるアミロペクチン単位鎖の分析

（鹿児島大・生物資源化学） ○花城 勲、檜作 進、安部 淳一

〔目的〕HPAEC-PAD 法は重合度の低い領域の単位鎖を個別に高感度で検出する事が可能な 新しい分析法である。ここでは、HPAEC-PAD 法によるアミロペクチン (AP) 単位鎖の分 布の測定法について検討し、若干の植物種についてA P 単位鎖の分布を検討した。

〔方法〕A Pの枝切りはPseudomonas イソアミラーゼ0.03U/mg A P、 $45^{\circ} \mathrm{C}$ 条件下で、 12時間反応させて行った。HPAEC はCarboPac PAlカラムを直列に 2 本連結して用い、溶媒 に $150 \mathrm{~m}$ 水酸化ナトリウム（A液）と $500 \mathrm{mM}$ の酢酸ナトリウムを含む $150 \mathrm{mM}$ 水酸化ナトリ ウム（B液）とを使用し、B液の濃度を漸増させるグラジエント溶出を行った。今回はグ ラジエントプログラムおよびクロマトグラフィーに供するサンプルの濃度について検討し た。単位鎖の分布はピーク面積の百分率により示した。

〔結果〕供試した粳米（ＩＲ４２）、糫米（女鶴糯）、コーン（白色デント）、馬鈴薯（ 紅丸、中性単位鎖画分）の $\beta$-アミラーゼの分解限度はそれぞれ95、96、95、99\%、数平

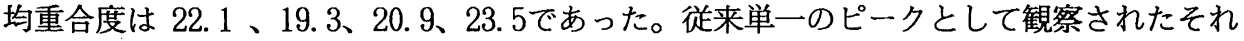
ぞれの単位鎖のピークに、今回の条件では小さな肩又はピーク間に微小なピークが観察さ れた。これらの結果は $\beta$-アミラ一ゼの分解限度の值とともに、アミロペクチンにはイソ アミラーゼによって分解されない分岐結合があることを示唆している。また、今回の条件 では重合度 80 付近の単位鎖までを単一のピークとして分析できた。HPAEC-PAD 法により 得た単位鎖の分布は、各々の植物種に固有であると思われる形状を示した。米の 2 品種間 では分布の相違は殆ど無く、米とコーンでは低分子側で僅か、米と馬鈴薯の中性単位鎖と の間では大きな相違があった。

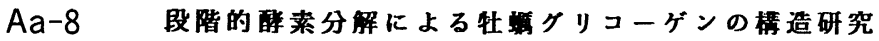

(大阪市大、*甲南女子大・家政) $O$ 三崎 地、松井元子、*角田万里子

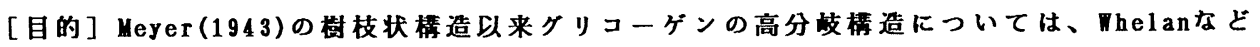
醉素法を主とした多くの研究があるが、解析手法などの限界で、微湅棒造は必ずしす明確 に把提されていない。しかし、最近、精密隆イオンクロマトクラフィー(HPAEC)が可能とな

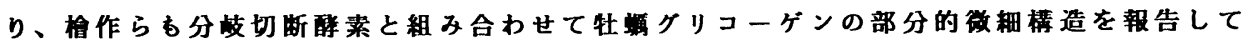

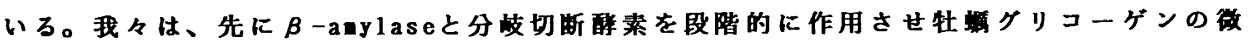
相棒造について、ある程度の知見を得たが、更に、HPARC(Dionex BioLC) による椎鎖の精

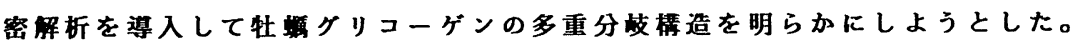

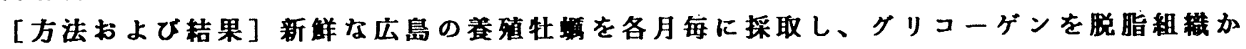
らDMSOで抽出，精製した。I soanylaseで完全に枝切り後、 $\alpha-(1 \rightarrow 4)$ unit鎖の分布をHPAECで

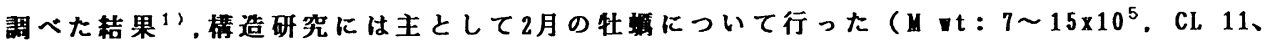
鎖長分布：2〜37)。このグリコーゲンに $\beta$-anylaseを作用させて得られる $\beta$-1init dext$\operatorname{rin}(\beta-L D 1) の A$ 鎖に由来するstub(G2+G3，1:1)をpu11ulanaseで除去し（SFD1）、これに -anylase,ついで pullulanaseを作用してB1鎖に由来するstubを除去、得られたSFD2に更に B-anylase, pullulanaseを作用させ、B2镍に由来するstubを除去----。この即階的醉素分 解による分子の外層から内層に向加ってのpeelingを程り返し、各即階でのdextrinのオリ コ糖鎖の解析を行った。HPAEC剽定值の定量化は小泉らのdataを参考にした。この耛果、牡

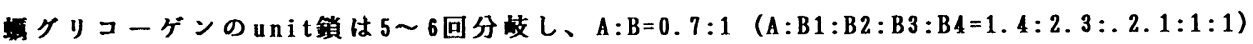
が得られ、基本的にはMeyerモデルを支持する。Pullulanaseによる繰り返しのtriningの結 果。更に $\boldsymbol{\alpha}$-amylasekよる生成分枝オリゴ粒の構造についても述へる。 1) M. Matsui, M.Kakuta; A. Misaki, Biosci., Biotech., Biochem. $57(1993) 623$. 
Aa-9 熱帯産砓粉より分離したアミロペクチンの物性について

（東京農大, 栄養，“総研）・石井靖子, 川端晶子; *中村道徳

[目的］ 演者等は熱帯産泚粉の構造とその物性との関係を解明するため, 食用カン ナ，アロールート，キャ,サバ,サゴの躬粉，および対照として馬鈴薯ととうもろこしの 激粉を選び，それぞれのアミロース，アミロペクチンにつき，その分子特性 ${ }^{1)}$ を、たた アミロペクチンについては平均鎖長分布 ${ }^{2)}$, イソアミラーゼによる分解過程 ${ }^{3)}$ 等を検討 した。今回はアミロペクチンにつき示差走查熱量分析 (D S C) により老化の難易を検 討し，また曳系性の测定を試みた。

[方法］ D S C 测定はセイコー電子工業 S S C - 57 0，D S C - 10 を用いた。 $70 \mu \mathrm{L}$ の銀製容器を用い, 無水物換算で $20 \%$ になるようにアミロペクチンと水を加 え， $20 \cdot \mathrm{C} に 一$ 夜放置し十分吸水させた。これを $5 \cdot \mathrm{C}$ の冷室に移して老化させた。测

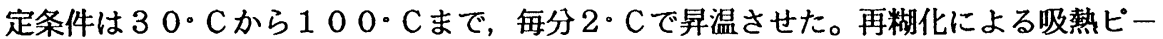
クの出現を経時的に観察した。また曳系性については, 曳系性测定用に改良した山電

（株）製レオナー（R E - 3305 ）を用いた。2\%および $4 \%$ の溶液になるようにそ れぞれアミロベクチンと水をねじぶたつき試験管にはかりこみ，暖めながら，よく振擝 して均一な溶液を調製しこれにつき試みた。

[結果］ 各アミロペクチンのD S Cの結果, 再糊化による吸熱ピークが現れるのに は差がみとめられ，馬鈴薯と食用カンナははやく，キャッサバは大変おそく，老化がは じまるようである。曳糸性について，エネルギー，応力，ひずみについて検討した。
1）石井靖子他
: 泚粉科学, 38, $333-342$ (1991)
2）石井靖子他
: 激粉科学, $37,251-257(1990)$
3）石井靖子他
: 啭粉科学, 投稿中

Aa-10 食味の異なる国内産米搌粉の分子構造の検討 （江南女子短大・生活科学, $*$ 三重大・生物資源）

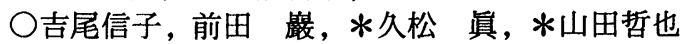

[目的］ 米の食味の相違は、そのアミロース含有量及びアミロペクチン分子の構造と の関連性が高いと考えられているが、国内産米において、そのアミロース及びアミロペク チンを分別精製して比較検討した報告は数少ない。本研究では、生産地及び品種の異なる 国内産米より澱粉を抽出し、その熱糊化特性等を調べると共に、アミロース及びアミロペ クチンを分別精製し、その分子構造についての検討を行った。

[方法］試料米として1989年産ゆきひかり、きらら397号(北海道)、コシヒカ リ(新潟県)、日本晴(滋賀県)、黄金晴、レイホウ(佐賀県)の 6 種を用い、冷アルカリ浸漬 法によって各澱粉を抽出した。これらの澱粉について青価（Blue Value）、最大吸収波長 （入 max）、ミクロビスコアナライザーによる粘度特性、示差走査熱量計（DSC）による熱 糊化特性の測定等を行った。また、これらの澱粉から、檜作・竹田らの方法によりアミロ 一ス及びアミロペクチンを分別精製し、その純度はTSKgelTOYOPEARLHW75Fによって検定し た。アミロースについてはさらにTOYOPEARLHW65F及びHW55F連結カラムによって分子量分布 を調べた後、3 区分してHPLC-RI-LALLSにより重量平均重合度を求めた。またアミロペクチ ンについてはイソアミラーゼを作用させ、TOYOPEARLHW50Sによってその鎖長分布を調べた。

[結果］ DSCによる測定の結果、To $\left({ }^{\circ} \mathrm{C}\right) 、 \mathrm{Tp}\left({ }^{\circ} \mathrm{C}\right) 、 \mathrm{Tc}\left({ }^{\circ} \mathrm{C}\right)$ と各澱粉のBlue Valueとの間 には高い相関がみられた。またアミロースのGPCによる分子量分布は、佐賀県産の 2 品種に、 より高分子側にシフトしたピークが得られ、特に黄金晴アミロースはその重量平均重合度 が（Fr-1:15700、Fr-2:8200、Fr-3:1860） とかなり高かった。さらにアミロペクチンにイ ソアミラーゼを作用させたところ、黄金晴の還元糖生成量が特に低いことから、国内産米 の中にも構造的に特徵のあるものが存在することが示唆された。 
Aa-11調理用新品種馬鈴薯の澱粉の分子構造と性質

（大阪女子大・基礎理，・鹿児島大・生物資源化学）

○鈴木綾子, 金山陸子, “柴沼 清, “安部淳一, 一竹田靖史, ・檜作 進

[目的]馬鈴著新品種は、プロトプラスト㕕種手法により育成されたすので、紫皮のも の (パープル) と赤皮のもの（レッド）がある。ともに卵形のいむで、肉質は粉質でほく ほくしており、黄色でべイクドポテトやサラダなどに用いられる。それぞれより涮粉を調 製し、分子構造と性質を検討した。

[方法］馬鈴薯より冷水で粗澱粉を調製し、トルエン処理し除タンパクした後、85\%熱

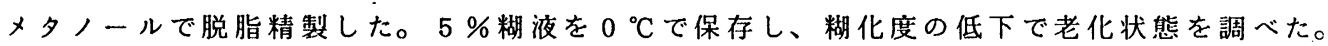
アミロースとアミロペクチンの分別は、インアミルアルコールと $\mathrm{n}-$ ブタノールを用いる

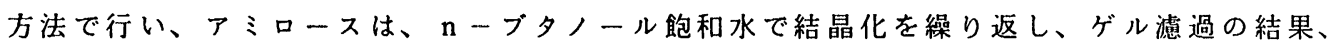
均一な標本を得た。分析の方法は、既報1.2)の方法によった。

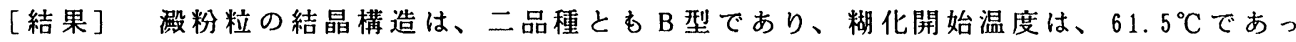
た。澱粉の老化性は、根系46号やエニワと比較するとやや老化しやすい傾向がみられた。 アミロース含量は、パープル21.7\%、レッド $21.0 \%$ 、リン含量は、それぞれ $743 \mathrm{ppm}$ と 652 $\mathrm{ppm}$ であった。 $\beta$-アミラーゼの分解限度は、何れも澱粉が $68 \%$ 、アミロペクチンが $56 \%$ 、 アミロースは、パープル85\%、レッド87\%であった。アミロースの数平均重合度は、パー

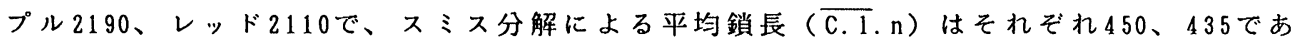
った。アミロペクチンのイソアミラーゼ分解法によるC.1.nは、ともに23.1であった。ラ

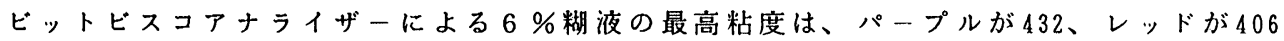
で、エニワ（409）に近く、根系46号（282）より高かった。

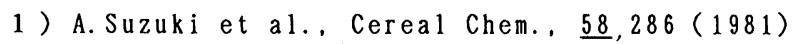

2) A. Suzuki et al., Cereal Chem., 69,309 (1992) 
Ap-1＼cjkstart水一エタノール 2 成分溶剂加熱処理による澱粉の物性変化

\section{（福山大 食品工学） 野口征浩、藤岡清文、○倉掛昌裕、小巻利章}

（目的） 澱粉を湿熱処理、温水処理等の加熱処理することでその膨潤度、溶解度、酵 素消化性などの物性が変化し、その処理澱粉の有効利用が注目されている。本研究では 水一エタノール 2 成分系におけるコーンスターチの加熱処理を行い、その水分組成の変 化にともなう澱粉の物性変化について検討を行った。

（方法） 水一エタノール 2 成分溶剂加熱処理の手順は、コーンスターチ $10 \mathrm{~g}$ にタ ノール0ー70\%とした水ーエタノール混合液 $50 \mathrm{ml}$ 加え密閉しオートクレーブで主 として $120{ }^{\circ} \mathrm{C} 、 20$ 分加熱するものである。その後冷却し水、アセトン、エーテル の順で洗浄し風乾し試料とした。酵素消化性は澱粉 $2 \%$ を $\alpha$ ーアラーゼ（スピターゼ L H ; ナガセ生化学（株）製） $12 \mathrm{DUN} / \mathrm{ml}$ で $40{ }^{\circ} \mathrm{C} 、 10$ 分反応させ生成全糖量を フェノール硫酸法で測定することで求めた。吸着実験は澱粉 $0.2 \mathrm{~g}$ に所定濃度の $\alpha$-ア ミラーゼを $5 \mathrm{~m}$ । 加え、撹拌下 $4{ }^{\circ} \mathrm{C} 、 30$ 分間の条件で行った。膨潤度および溶解度 は澱粉 $0.5 \%$ 、温度 25-100 $\mathrm{C}$ 、保持時間 30 分の条件で測定した。そのほかに 示差走査熱量計（ＤＳＣ）およびアミログラフィによる測定を行い糊化特性についての 検討を行った。

（結果） 該加熱処理での水一エタノール混液の水分組成を０から７０％と増加させる ことでコーンスターチの膨潤度および溶解度は低下し、また、 $\alpha$ ーアミラーゼの消化性 および吸着性は增加する傾向が認められ、澱粉物性変化の制御ができることがわかった。

これらの性質は水分組成 $30 \%$ 以上の処理で大きく変化し、この水分組成近傍におい て澱粉構造が大きく変化することがわかった。

Ap-2 米滩粉ゲルの安定性とゲル化・溶融ブロファイルに及ほす乳化娮の構成脂肪 酸種の影䇺

（新潟大教育、 $*$ 三菱化成）○睠田啓子、八木小絵子、 ${ }^{*}$ 日下部正裕、 ${ }^{*}$ 三浦靖

〔目的〕これまで、米潄粉ゲルの速度論的解析を武み、糖がゲル中の水を構造化するこ とにより渐粉ゲルが安定化され、硬化（老化）が抑制されること、また各種乳化剤の添加 により、ゲルの老化抑制効果は必ずしもアミロース複合体形成能に依存するものではなく、 モノエステル含量に大きく左右されることを明らかにしてきた。本研究では、ショ糖脂肪 酸エステル（SE）を用いて、老化過程での米汯粉ゲルの安定性および糊化過程でのゲル 化・溶虽プロファイルに、構成脂肪酸の炭素鎖長がどのような影搖を及ほすかを検討した。

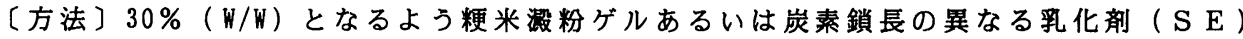
添加ゲルを調製し、 $0^{\circ} \mathrm{C} に （ 50$ 時間まで）貯蔵した。（株）山電製のクリープ・メータ一、 レオナーRE-33005を用いて、経時的にクリープを湘定し、クリープ・コンプライアンス值 の眝蔵時間依存性を一次反応速度式 $\log \mathrm{J}=-\mathrm{k} \mathrm{t}+\log \mathrm{J}$ 。で近似し、 $\mathrm{k}$ (硬化速度) とJ。（初期值）を算出し比較検討した。（株）レオロジ製の動的粘弾性装置MR-300にて、 昇温速度 $1^{\circ} \mathrm{C} / \mathrm{min}$ 昇温速度で、糊化過程でのゲル化・溶融ブロファイルを求めた。

〔結果〕脂肪酸種を直鎖飽和脂肪酸 $\mathrm{C}_{8}:$ :日のプリル酸から $\mathrm{C}_{18: 0}$ ののステアリン酸まで 変化させたショ糖脂肪酸モノエステル ( S E ) の硬化速度 (k) 一トが最も小さくなった。モノグリセリドでは、アミロースとの複合体形成能がパルミチ ン酸で最大となり、アミロペクチンとの複合体形成能は脂肪酸の炭素鎖長が長いほど大き いことが知られており、SEの場合も、パルミチン酸が硬化抑制の至適鎖長脂肪酸である ことが判明した。 S E 添加のゲル化・溶融プロファイルは、無添加あるいは糖添加のフロロ ファイルと大きく巽なり、 $\mathrm{SE}$ が糊化初期過程での潄粉粒子の膨潤を大きく遅延させてい ること、遅延効果は C $16:$ S E で最大になることが明らかになった。 
Ap-3＼cjkstart高圧処理後の餅生地の物性と食味特性に関する研究

（武蔵丘短大・健康生活, “果農大・農, **東農大・総合研究所）

○永岛伸浩，小板由美子，"川蝡晶子，"*中村道德

【目的】近年、食品に高圧処理を施す研究が盛んになり、ジャム類や畜肉類ですばらし い成果をあげており、澱粉性食品においても期待が持たれている。飭生地は糯米を水とと もに加熱し、物理的な力を加えることによって生地が調製されるが、調製法や保存法を変 えることにより餅生地の硬化の程度や食味時のテクスチャーが異なることがこれまでの研 究で明らかとなった。今回は基礎的な研究として調製直後や保存後の䬼生地に高圧処理を 施し、物性の変化や食味特性を中心に検討した。

【方法】 1) 䭉生地の調製：前報 ${ }^{1)}$ と同条件で電動スタンプ式（S 式）、電動ミキサー式 （M式）の餅生地を調製し、調製值後，一定時間冷凍 $\left(-20^{\circ} \mathrm{C}\right)$ および冾蔵 $\left(5^{\circ} \mathrm{C}\right)$ 保存した 試料を用い、坂下製作所製加圧機を使用して、200M P a の加圧で行った。

2) 研究方法

:それぞれの餅生地について (1) 顕㞦鏡による組織構造の観察、(2)レオナー（(株)山電RE -33005型）によるクリープ測定および解析、（3)同レオナーによる破断特性、(4)ペネト ロメーターによる針入度試験、(5) シャーメーターによる剪断試験、(6)官能検查による食 味特性について検討した。

【結果】光学顕锄鏡による組織観察の結果、高圧処理した餅生地は調製直後の生地（S， M式とも) では組織中の気泡がほとんど消失し、硬化後の生地は組織中の気泡が変形し、 また巨大な気泡（空烣）ができた。クリープ測定の結果、高圧処理した生地は S, M式と もに粘弾性の值がやや大きく硬い生地であることが、針入度試験の結果、冷蔵 24 時間保存 後の生地に高圧処理をすると硬化の程度がより增加して行つた。食味特性の結果、高圧処 理した生地は柔らかいが伸びが少なく、食べやすい生地であることが認められた。

1) 永岛伸浩他：測粉科学 $34,179-185$ (1987).

Ap-4 半生冷麺（澱粉麺）製造における物性変化

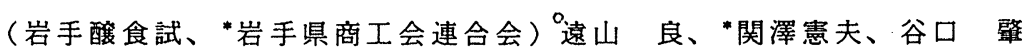

[目的]冷麺は盛岡の特産品として、近年急速にその生産量が伸びている。冷麵は小麦 粉を中心として馬鈴薯澱粉（３０％）原料とする澱粉麺で、半生冷麺は両者をこね合わ せたものを連続押し出し機（（1000 00 C （2 分）した後包装し、再び加熱処理（８００Ｃ４０分）して製品としている。今回は加熱 処理前後の試料を中心に麺及び澱粉の物性変化について調べたので、その結果について報 告する。

[方法]実験に用いた試料は、半生冷曙製造工場の各工程よりサンプリングした。ゆで 試験は $10 \mathrm{~g}$ の試料を、遝流冷却器付きの丸底フラスコに入れた $250 \mathrm{~m} 1$ の水で 12 分 間ゆで、経時的に赬の水分含量およびゅで溶出量を測定した。麺の（澱粉）の糊化度の測 定はRhizopus niveus由来の酵素を用いてグルコアミラーゼ法により行った。X 線回折用の 試料は通風乾燥した後粉砕して調製し、測定は理学電機俶製を用い、対陰極 $\mathrm{Cu}$ u、フィル

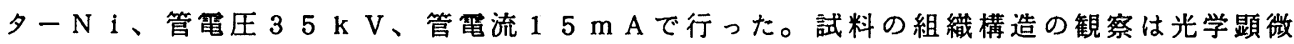
鏡および走查型電子顕微鏡により行った。

[結果] 上記の各試験において加熱処理前後の試料で変化が最む大きかった。加熱処理 前の湎の 8 分後のゆで溶出量は $31.7 \%$ 、加熱処理後の缅は $19.5 \%$ であり、加熱処 理によりゅで溶出量は 38 ８５％減少した。また、加熱処理前の試料の糊化度は $93 \%$ で、 加熱処理後は75\%になった。更に、加熱処理前の試料の X 線回折図形ではピークは観察 されなかったが、加熱処理後の試料では $2 \theta=17^{\circ}$ 位置にピークが観察された。以上の 結果から、加熱処理する事により澱粉の老化度が進み、半生冷麺に特有の物性が付与され る事が判明した。 
Ap-5 化工小麦測粉 の調理・加工特性 (IV)

$\begin{array}{lrlll}\text { 共立女大家政 } & \text { O高橋 } & \begin{array}{l}\text { 節子 内藤 } \\ \text { Kansas State Univ. }\end{array} \text { Paul } & \text { A. Seib } & \text { 平尾和子 }\end{array}$

[目的]近年、冷凍食品の增加に伴い老化しにくい知粉に対する要望が高まり、天然㴊粉 に物理的・化学的処理を施して物性を変化させた各種の化工澱粉の利用に関心が向けられ ている。本報告では、天然の小麦知粉に比べて糊化温度が低く遁明度の高い糊か得られ、 低温保存や凍結 - 解凍安定性の期待されるヒドロキシブロピル化小麦没粉を試料として理 化学的性貿ならひに糊やゲルの性状から調理・加工食品への利用を試みた。

[方法] 試料としたヒドロキシプロピル小麦（以下HPWという）渐粉は米国Midwest Grain Product Midsol 4,42,46をを用い、比較として米国で広く使用されているヒドロキシ プロピルワキシーメイス（以下 HPWMという）殹粉はNational Starch and Chemical Corporation 用いた。X 線回折、鶖分析、膨洞度・溶解度、Rapid Visco-Analyzer（フ オス・エレタトリリク・ジャイン（花）による粘度の測定および動的粘弾性の测定を行い、実際の調理面 から筑粉シートやスープをとりあげ低温貯蔵安定性や耐老化性の面から添加奻果を㛟討し た。

[結果] HPW没粉は $65^{\circ} \mathrm{C}$ 以下ではHPWM殹粉よりも高い粘度を示すか、 $70^{\circ} \mathrm{C}$ 以上での粘度は 低い。HPW知粉の膨洞力はHPWM晸粉に比べて低いか、溶解度は顕著に高い項向を示した。

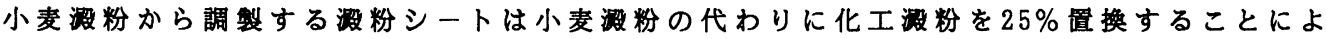
り透明度を增し、低温保存時の安定性を增す傾向が認められた。测粉糊液の動的粘弾性の

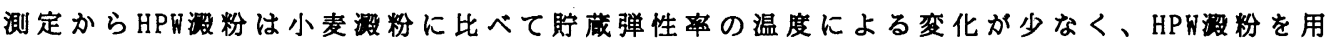
いた冷製スーブは低温保存時においても物性变化が少なく、また凍結・解凍安定性が大で あった。

Ap-6 パノースシラップの特性および能蝕防止糖質としての利用

（日本食品化工、" ${ }^{*}$ 林原生化研、 ${ }^{* *}$ 大阪大・菌学部）

○村松正善、中久喜輝夫、*竹内叶、 ${ }^{* *}$ 大嶋隆、**浜田茂幸

【目的】パノースはグルコースが $\alpha(1 \rightarrow 6)$ および $\alpha(1 \rightarrow 4)$ 結合してできる 3 糖類で、ビフィズスファクターあ るいは抗兓蝕性糖質として最近注目されている。演者らは破粉糖化液に $\alpha$ ーグルコシダーゼを作用させ大量にパノースシ ラップを得る方法を確立し、その特性および能蝕抑制効果を解析した。

【方法】パノースシラップの一般物性およぴパノースの定量は洊粉糖関連工業分析法に従った。また、パノースシラッ プに含まれているグルコースおよびマルトースをそれぞれ0.3\%および1\%以下に調製した高純度パノースシラップはカチオン 交換樹脂カラムクロママトグラフィーにより調製した。坑解蝕性試験は供試細菌としてStreptococcus sobrinus 6715株を生後 18 日秢のラットに感染させ、各種桾質を含む飼料を 1 群 12 匹のラットに与えて、それそれの糖質の解蝕誘発能を調へた。

【結果】澱粉糖化液に $\alpha$ ーグルコシダーゼを作用させると、マルトースよりパノースが生成され、さらにパノースより イソマルトースが生成されることが明らかになった。このため、醳素反応時間、および醉素添加量を減らすことによりパ ノースの生成量が最大（30〜3 2\%）になる条件を設定した。この設定条件下で得られたパノースシラップの一般物性を 調べたところ、甘味度が砂糖の $45 \%$ であること以外はほぼ砂糖と同じ特性を示した。また、このシラップのパノース画分 を逆相クロマトグラフィーにより分画し、NMRにより解析したところ、イソパノースは全く含まれておらず、パノースの 単一画分であった。ラットを用いた解蝕誘発実験では、パノースシラップ、高純度パノースシラップの両者とも極めてわず

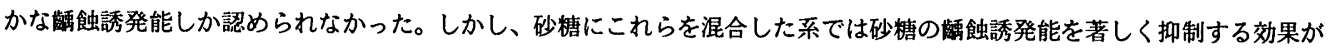
示めされた。 
Ap-7 ネオプルラナーゼの糖転移反応により生産した新イソマルトオリゴ糖シラップの in vitro で の機能性評価

(江崎グリコ生化研) ○柳瀬美千代、栗木 隆、高田洋樹、岡田茂孝

【目的】私達はネオプルラナーゼの糖転移反态を利用して、澱粉から新しいタイプのイソマルトオリゴ糖シラ ップが製造できることを明らかにした(1)(2)。この新イソマルトオリゴ糖シラップは $\alpha-1,6$ 結合をもつイソマ ルトオリゴ糖を $60 \%$ 以上の高比率で含んでおり、グルコース含量が、市販イソマルトオリゴ糖シラップの約 1/2であることから、ビフィズス菌の活性化及び虫歯予防の効果が期待できると考えられる。腸内ビフィズス 菌の增殖因子となるイソマルトオリゴ糖は、消化管酵素による分解を受けにくく、大腸に到達してビフィズス 菌に資化されるものといわれている。そこで新イソマルトオリゴ糖シラップの機能性を調べることを目的とし て、小腸での消化性を in vitro でモデル実験した結果について報告する。さらに、虫歯予防効果を確認するた め虫㐘菌による酸及び不溶性グルカン生成について in vitro で検討した結果についても報告する。

【方法および結果】市販ラット小腸アセトン粉末を新イソマルトオリゴ糖シラップ、ハイマルトースシラップ 及び市販イソマルトオリゴ糖シラップに作用させ消化性を調べた。その結果、新イソマルトオリゴ糖シラップ は市販イソマルトオリゴ糖シラップと同様、ハイマルトースシラップと比較して明らかに分解性が低かった。 次に、新イソマルトオリゴ糖シラップの Streptococcus mutans による酸生成について経時的に調べ、各種才 リゴ糖シラップの場合と比較した。一定時間反応後、シュクロース、グルコース及びハイマルトースシラップ は初発 pH 7 から pH 5 以下まで、市販イソマルトオリゴ糖シラップでも pH 5.6 まで低下した。しかし、新イ ソマルトオリゴ糖シラップでは pH 6.3 と大きな低下は見られず、虫歯菌による酸生成は少ないことが明らか になった。又、シュクロース、グルコース及びハイマルトースシラップに見られるような虫歯菌による不溶性 グルカンの生成も見られなかった。

(1) Kuriki, Yanase, Takata, Takesada, Imanaka, \& Okada. Appl. Environ. Microbiol. 59: 953-959 (1993)

(2) Kuriki, Yanase, Takata, Imanaka, \& Okada. J. Ferment. Bioeng. (in press)

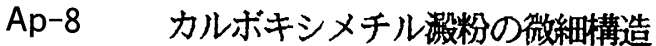

（近畿大・薬）○坊木佳人, 川崎直人

[目的］カルボキシメチル激粉の水分収着量は，カルボキシメチル基の置換率の上昇に伴

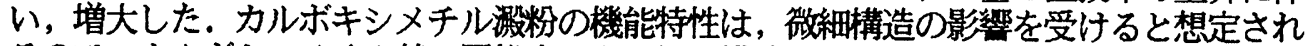
るので,カルボキシメチル基の置換率による細孔構造の変化について検討した。

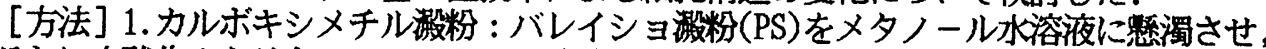
それに水酸化ナトリウムとモノクロル酸を加え, $60^{\circ} \mathrm{C} て ゙ 6$ 時間反応させ, それぞれ, 置 換率0.131,0.296, 0.638,0.810,1.010のカルボキシメチル澱粉Na-CMS(1), Na-CMS(2), NaCMS(3), Na-CMS(4), Na-CMS(5)を調製した。2.窒素吸着等温線 : Na-CMSを五酸化燐の入 ったデシケータ中で3筒月真空脱気し，液体窒素温度で容量法により吸着等温線を求めた。 3.細孔分布 : 窒素吸着等温線を用い, micropore法とDollimore-Heal法で算出した。

[結果] 窒素吸着等温線は, PSにカルポキシメチル基を置換することにより，大きな変化 か認められた。置換率 0.638以下ONa-CMS(1)〜(3)の吸着量は，PSに比べ，相対圧 0.5 以 下で変化がなく，0.5以上で著しく増大した。置換率 0.810 以上のNa-CMS(4),(5) の吸着 量は, PSに比べ, 全相対圧において増大した. PSの表面積は0.22 $\mathrm{m}^{2} / \mathrm{g}, \mathrm{Na}-\mathrm{CMS}(1) \sim(5)$ の

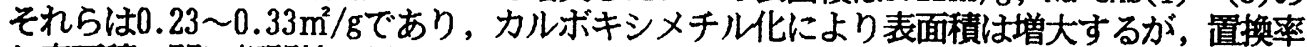

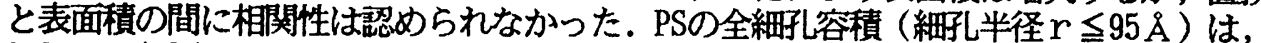
$3.0 \times 10^{-4} \mathrm{ml} / \mathrm{g}$ であり, Na-CMS(1)〜(5)のそれらは, $4.4 \times 10^{-4} \sim 5.4 \times 10^{-4} \mathrm{ml} / \mathrm{g}$ であった。

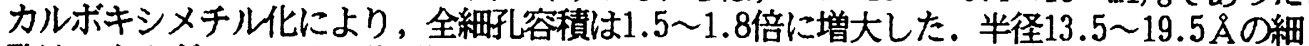
孔は，カルボキシメチル化（置換率 0.683 以下）により消失したが, 置換率 0.810 以上で

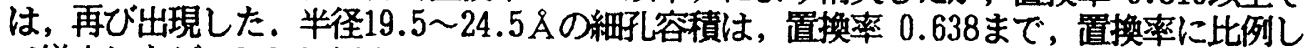
て増大したが, 0.810 以上では, PSとほほ同体積を示した。これらの細孔分布の結果から， PSをカルボキシメチル化すると，置換率により钽細棈造は大きく变化すると考えられる。 
Ap-9 Gluconobacter oxydans の生産するデキストランの構造

(日本食品化工、*静岡大・教育、**静岡大·応生化)

○海野犅裕、中久喜輝夫、”岡田唶太郎、“*碓氷泰市

【目的】Gluconobacter oxydans ATCC 11894を測粉加水分解物を炭素源として培養する

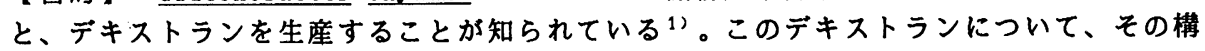
造解析を行ったので報告する。

【方法】G. oxydans ATCC 11894 を轺粉部分加水分解物と酲母エキスからなる培地で、

$25^{\circ} \mathrm{C}, 7$ 日間培養し、Hehre ら ${ }^{1)}$ の方法に従ってデキストランを調製した。得られたデ キストランを、N M R 解析, メチル化分析, 各種デキストラナーゼ等を用いた醭素分解等 を行いその構造を解析した。

【結果】デキストランの N M R 解析では $\alpha-1,6$ - グルコシド結合に由来する強いシ グナルが観察され、その他には $\alpha-1,4-$ グルコシド結合に由来する弱いシグナルが観 察された。また、Arthrobacter globiformis I 42起源のグルコデキストラナーゼによりほ ほ完全に加水分解され、两. Blobiformis T6 起源のイソマルトデキストラナーゼでは約 $23 \%$ の分解限度を示した。以上の結果から、G. oxydans ATCC 11894 の生産するデキス トランは、Leuconostoc mesenteroides NRRL 512F 起源のデキストランとは構造が異なり、 $\alpha-1,6$ - グルコシド結合の主鎖に $\alpha-1,4-$ グルコシド結合の側鎖を有するものと 推定された。

本研究は静岡県産学共同研究開発事業の一環として行われた。

1) E.J.Hehre and D.M.Hamilton : Proc. Soc. Exp. Biol. Med., 71, 336-339 (1949)

Ap-10 アズキ種子中のアラビノガラクタンについて

(岐阜大学連合農学研究科, ·農学部) ○韋保烃, ·山内亮, ·加藤宏治

目的：我々はさきにアズキ種子(丹波大納言種、京都産) から冷水で抽出される多蛤は DEAE-SephadexA-50 ( C1-型) カラムクロマトグラフィーで水溶出画分と0.5M NaCl溶出画 分の 2 画分に分画され、水溶出画分の多糖は $a$ ーグルカンであることを報告したり。ここ では0.5M NaCl溶出画分について行った実験の結果を報告する。

方法及び結果：予備実験で $0.5 \mathrm{M} \mathrm{NaCl}$ 溶出画分の多糖は给水で抽出するより $0.5 \mathrm{MNaNO}$ て 抽出する方がより効果的に抽出されることが分かったので、同溶液を用いて多結を抽出し

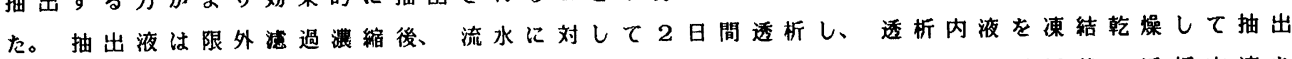
物F1を得た。F 1 は $\alpha$ ーアミラーゼ、次いでアクチナーゼ $\mathrm{E} て ゙$ 処理し、透析後、透析内液を 凍結乾燥して粗多糖F 2 を得た。F 2 は DEAE-SephadexA-50( Cl一型) カラムに供し、水溶出

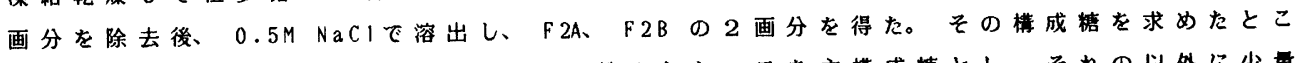

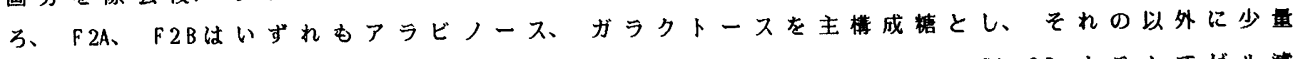
のグルコース、マンノース、キシロースが証められた。Sepharose CL-2Bカラムでゲル 過分析を行ったところ、溶出液に水を用いた場合、F $2 A 、 F 2 B$ はずれも䉓一のビークを

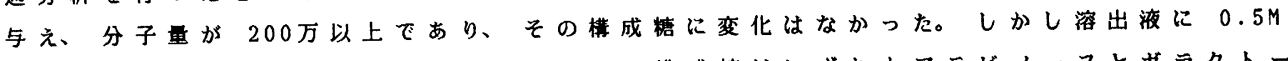
NaClを用いると、分子量は数万になり、その構成糖はいずれあアラビノースとガラクト一 スのみになった。以上ょりF2A、F2Bはそれぞれ夾雑成分として他の多糖を含むがの主成 分は互いに会合能力のあるアラビノガラクタンであると推定した。

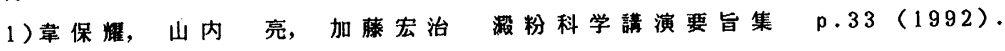


Ap-11 Candida H-404 株 $\alpha$-ガラクトシダーゼによる転移生成物の構造 （杉山産研、*ホーネンコーポレーション、狄大阪市工研） 橋本博之、○片山千栄、水小嶋 勝、炏北畑寿美雄

[目的］既に演者らは Candida H-404 株の生産する耐熱性 $\alpha$-ガラクトシダーゼは強い転移作用 と幅広い受容体特異性をもち、ペントースやヘキソースのみならずフコースの様なデオキシ糖や グルコサミン、N-アセチルグルコサミン等のアミノ糖、各種オリゴ糖、糖アルコール、多価アル コールなどを受容体とすることを報告した。また、受容体がメリビオース、ラクトース、シュー クロースのような 2 糖の場合、主転移生成物は $\alpha-1,6$ 体であることを報告した。今回は、グルコー ス、ガラクトース、N-アセチルグルコサミンなどの単糖類への転移生成物の構造を調べたので報告 する。

[万法］ 基質にラフィノース、あるいはメリビオース 0.29M を、受容体にグルコース、ガラク トース、N-アセチルグルコサミン 0.58M を用いて反応を行い、経時的に反応生成物を HPLC を用 いて分析した。HPLC 分析は配位子交換カラム (Shim-Pack SCR-101C) とアミノカラム (Asahipak NH2 P-50）により行なった。転移生成物を HPL により分取し、 $\alpha$-ガラクトシダーゼによる分解 メチ ル化分析、13C-NMR 分析などを用いてその構造を調へた。

[結果］基質の切断速度は、グルコースを受容体に用いた場合約 $1 / 2$ に、ガラクトースの場合 は約 1/5 に低下した。グルコース及びガラクトースへの主転移生成物は HPL のリテンションタイ 厶並びにその他の分析結果よりそれぞれメリビオース、 $\alpha-1,6$ ガラクトビオースであると同定し た。現在、N-アセチルグルコサミンへの転移生成物の構造を検討中である。

1) H. Hashimoto et al. Biosci. Biotech Biochem, 57 (3), 372, 1993

2) 橋本、片山、後藤、北畑 1993 年度日本農芸化学会講演要旨集 P. 119

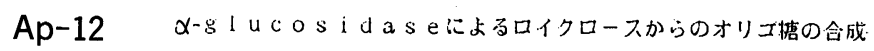

（大阪市大・理）○トリサンティ アニンタワテイ、古市公倯 飯塚 勝、南浦能至

（目的）強力な生でんぶん分解活性を示寸菌としてインドネシアで分離したアスベルギルス属の一系状菌をふすま智による固体培善 て培養し、生成した醇素の性貿を調べたところ、でんふん分解活性を有する画分のうち一つがマルチトリイトール（MT T) 分解 活性とグルコースの強い転移活性をしめした。そこでの画分を用い、2、3のオリゴ糖の合成を試みた。

（方法）醅素の精製は塩析、イオン交換、ゲルクロマトグラフィー等によった。 mesenteroidesのDextransucraseによりシュクロースから合成した。酳反応の生成物の追跡はHPLC により、また生成物の分離はＢｉＯＧ１Ｐ－2のクロマトにより行った。糖の同定はNMR、TL C及び醉素による分解生成物
の同定によった。

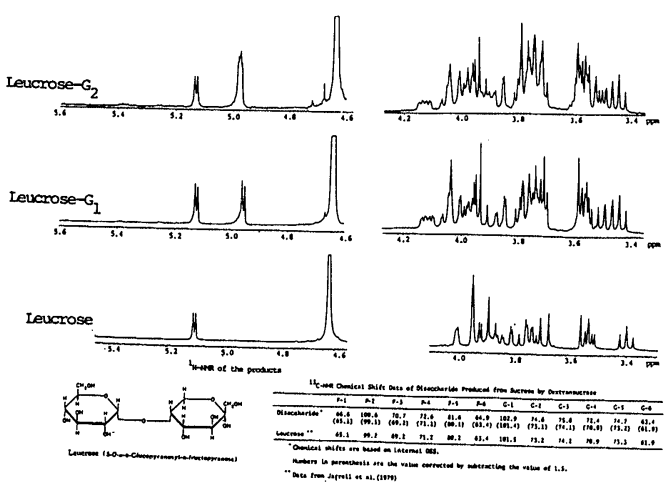

（結果）醊素の活性を可溶性でんふんんとMT Tを基質として測定 したところ、3つの画分をうることができた。

一つは $\alpha-g 1$ u cosidase画分、一つは $\alpha$ - amy 1a s e 画分、むう一つはg 1 u c o a my l a s e 画分と考えら 礼た。このう $\alpha-81$ u cosi d a s e 画分を用い、 ロイクロースと $30^{\circ}$ Cでインキュベートし、生じた生成物をBi。 G e 1 P - 2で分離した。3榶と 4 糖がえられ、これらは g l u c os i d a s e により最終的には構成糖にまで分解さ机 た。4粕はChaetomi um gracileのDextra n a s e で分解さ机て、ロイクロースとイソマルトースに分解 された。こ机らの結果とほかの2、3の性質から、本辞絜は $\alpha-1 、 6$ 結合の転移生成物を作りやすい $\alpha-g 1$ u c o s i da s eの一つとかんがえら机る。 
Ap-13 Leuconostoc mesenteroides シュークロースホスホリラーゼによるフェノー

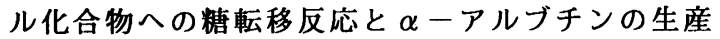

（キッコーマン・研究本部） ○北尾俉、堀内達雄、関根廣

【目的】我々はすでに、乳酸菌L. mesenteroides起源のシュークロースホスホリラーゼ が、糖類 ${ }^{1)}$. カテキン類 ${ }^{2}$ を受容体として糖転移反応を行なった場合の基質特異性につい て報告した。今回は、シュークロースを供与体、フェノール及びその関連化合物を受容体 とした場合の特異性について詳細に検討した。

【方法】酵素の精製及び活性の定義は、既報 ${ }^{3)} に$ 準拠した。各種フェノール及び関連化 合物からの糖転移生成効率は、TSKgel ODS-80T $\mathrm{M}$ カラムを用いた液体クロマトグラフィー (HPLC)から、全体のピーク面積に対する転移産物のピーク面積比で表わした。また、ハイ ドロキノンからの糖転移産物の精製は、活性炭カラムを用いたクロマトと分取用ODSカラ ムを用いたHPLCによって行なった。

【結果】本酵素は、幅広い受容体特異性を示し、ハイドロキシベンゼン類・ハイドロキ シ安息香酸類・ベンジルアルコール・ハイドロキシベンジルアルコール類などヘグルコシ ル基を転移した。フェノールとベンジルアルコールで比較すると、転移効率はハイドロキ シメチル基よりフェノール性水酸基の方が高かった。二つのフェノール性水酸基が降接し た化合物（カテコール）、フェノール性水酸基とカルボキシル基が隣接した化合物（2-ハ イドロキシ安息香酸) 及びフェノール性水酸基とハイドロキシメチル基が隣接した化合物 (2-ハイドロキシベンジルアルコール) に対して特に転移効率が高かった。また、2.0gの ハイドロキノンから $2.3 \mathrm{~g}$ の転移産物が得られ、この構造を酵素分解・N M R などにより解

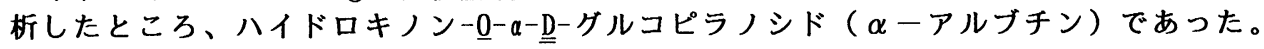

1) Biosci. Biotech. Biochem., 56, 2011-2014（1992）. 2) 日本農芸化学会1992年度大 会講演要旨集 p. 249. 3) Agric. Biol. Chem., 55, 1805-1810 (1991).

Ap-14ジアルデヒドーデキストラン糖鎖の導入によるトリプシンの性状改変

（第 2 報）修飾トリプシンの性質と構造

（山崎製パン・中研, *農水省・食総研） ○高津浩一郎, *小林幹彦

【目的】クリニカルデキストラン (CL)のジアルデヒド誘導体であるジアルデヒドーデキ ストラン (D-CL) をトリプシンに結合させ, より安定な修飾酵素 (D-CL-トリプシン) を得る ことができた ${ }^{1)}$ 。本報告では D-CLートリプシンを精製し, トリプシンとD-CLが結合してい ることを明らかにすると共に修飾酵素の性質及び構造について検討を行った。

【方法及び結果】CLを $\mathrm{NaIO}_{4}$ で過ヨウ素酸酸化することにより，D-CLを得た。 D-CLのア ルデヒド化率は完全加水分解後HPLCにより分析を行った結果 $62 \%$ であった。トリプシン とD-CLの結合反応は $\mathrm{pH} 8$ ．5 のトリエタノールアミン緩衝液中で行った。反応液をゲル濾 過 (Toyopear1 55S) 及びイオン交換 (DEAE-Toyopear1 650M)により精製した結果, タンパク ・糖・トリプシン活性の溶出ピークは完全に一致した。これよりトリプシンとD-CLが複合 体を形成し活性を保持していることが明らかとなった。フェノール硫酸法による糖の定量 とUV $280 \mathrm{~nm}$ の吸収によるタンパクの定量から, 修飾酵素の糖とタンパクの比率はほぼ 1 対 1 であった。修飾酵素の分子量はタンパク換算で 9 万ダルトン, 等電点はディスクゲル 電気泳動の結果 6.7 であった。またTNBS法によるアミノ基の定量から, D-CLートリプシ ンの修飾率は $64.7 \%$ であった。修飾酵素を $\mathrm{NaBH}_{4}$ で還元するとシッフ塩基由来の 31 $0 \mathrm{~nm}$ の紫外吸収が消失した。これよりトリプシンとD-CLの結合にシッフ塩基の関与が示唆 された。さらに修飾醉素の基質特翼性を調べるためにインスリン B 鎖とアンジオテンシン I に作用させ，切断フラグメントをネイティブトリプシンによるものと比較したが, 基質 特異性の変化は認められなかった。

1 ) 小林, 高津 : 農芸化学会大会講演要旨集, p326 (1993) 
Ba-1 Klebsiella pneumoniae由来プルラナーゼと鎖長の異なるオリゴ糖との相互作 用、○岩本博行、丸石一志、竹本正治、廣濑順造、廣海啓太郎、堺修造*（福 山大・工・食品工、“林原生化研）

[目的］溊粉枝切酵素に関する反応速度論的研究は、他の $\alpha$-アミラーゼに比へて遅れ ている。そこで今回は Klebsiella pneumoniae由来プルラナーゼと鎖長の異なるオリゴ糖 との相互作用を調へる事により、本䣼素の活性中心に関する情報を得る事を目的とした。

[方法］オリゴ糖として鎖長が 1 から 7 のマルトオリコ糖（アルコール）類を用い、 それぞれのオリゴ糖についてプルランを基質とした醉素活性の阻害より阻害物質定数（㟶i 值）を、325 nm付近の蛍光強度の変化から解離定数（员 值）を求めた。

[結果］まず鎖長の異なるマルトオリゴ糖アルコール類による阻害を調へたところ、 プルラナーゼは $\mathrm{G}_{2}$-01以上の糖アルコールによって阻害された。それぞれの糖アルコール

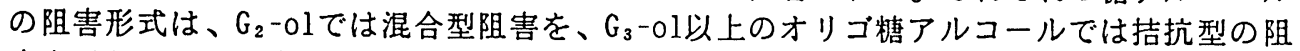
害を示した。また各オリゴ糖アルコールの $\mathrm{Ki}$ 值を調べたところ、 $G_{2}-01 て ゙ は 2$ m M前後、 G -olから G 示した。一方、鎖長が 3 以上のマルトオリコ糖（アルコール）が䣼素に結合すると $325 \mathrm{n}$ 咐近（280 nmで励起した場合）の蛍光強度が增加したが、これを利用して求めた $K \mathrm{~d}$ 值は、 鎖長が 3 小ら 6 になるにつれて約 4 听から 0.2 m॥まで減少し、鎖長が 6 以上ではあまり 変わらなかった。以前報告したプルラナーゼとシクロデネスリンとの相互作用では、阻 害から求めた Ki 值と蛍光変化から求めた $\underline{K} \mathrm{~d}$ 值がほぼ一致したのに対して、マルトオリコ 糖（アルコール）類では上で述へたように両者が一致せず、Kd值の方が 1 析から 2 桁大き い值を示した。この事から、本䣼素にはマルトオリゴ糖が結合する部位が少なくとも2 䉪 所存在し、搦い結合部位に蛍光変化を惹き起こすトリプトファン残基が存在すると考えら れた。(Iwamoto et al. (1993) J. Biochem., 113(1), 93-96)

Ba-2 Rhizopus-glucoamylaseの反応温度による作用最適 $\mathrm{p} \mathrm{H}$ 遷移について （福山大・生物工）○溝上恭平、桂浩明、高橋成幸、山本武彦

[目的］ Rhizopusのglucoamylase剂を用いて低温下 $\left(15^{\circ} \mathrm{C}\right)$ で生米からの直接アルコール 発酵をさせた所、p Hが5.0よりは3.5付近で発酵速度が速くなる現象が認められた。 この原因を解明するために、精製奋hizopus-glucoamylase標品を用いて検討した結果、その 反纫温度を下げる事によって䣼素の作用最適 $\mathrm{p} \mathrm{H}$ が酸性側に遷移することが明らかになっ たので報告する。

[方法］使用したRhizopus-glucoamylaseは S P-セファデックス、D E A E-セファデッ クス及び B i o-G e 1 P-1 5 0でのカラムクロマトグラフィーにより S D S-P A G E で笚一バンドを示すまで精製した。基質は糊化馬鈴署海粉、糊化あるいは生米澱粉を使用 した。 p Hの調整には酢酸或いは乳酸緩衙液を用いた。差スペクトルは島津U V-260を用 いて測定した。

[結果] Rhizopus-glucoamylaseの糊化涮粉に対する作用最適 p Hは $40^{\circ} \mathrm{Cでは} \mathrm{p} \mathrm{H} \mathrm{5.0.}$

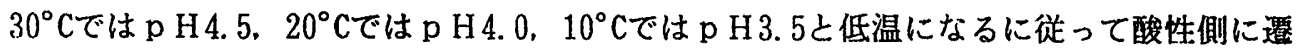
移した。この傾向は緩衝液の種類とは無関係に詯められた。また、温度を变化させて、その 差スペクトルを測定した所、オボアルブミンや牛血清アルブミンでは差は認められなかっ たが、 Rhizopus-glucoamylaseでは明らかな変化が認められた。温度による作用最適 p H の邆移について Asp. niger-glucoamylase, 細菌のa-amylase等についてもあわせて報告す る。 
Ba-3 マルトリオース生成アララーゼによる糖転移反応の位置選択性の検討

（日本食品化工， *静岡大・応生化）○小川浩一, “藪内嘉彦, ${ }^{*}$ 村田健臣,

*碓水泰市

【目的】演者らは既に，各種犺ゴ糖生成アララーゼの糖転移作用を利用した有用マルトオリゴ糖 誘導体（重合度 4-7）の簡易合成法を報告してきた。本研究ではStreptomyces griseus起 源マルトリオース生成アミラーゼ（G - amy lase）を用いた糖転移反応の際の位置選択性に及ぼす受容体 基質のアグリコン配向の影響について検討した。1)

【方法】マルトラトラオースを供与体基質，各種芳香族をアグリコン部に持つグリコシド誘導体または 如ビオースを受容体基質として, 各種親水性有機溶媒一水系中で，G 転移反応生成物の定量はH P L C を用い, 構造解析はNMRにより行った。

【結果】 $p$-nitrophenyl $\alpha$-glucoside(GP $\alpha$ )を受容体基質とし，50\%ジメチルスル杖シト中で 反応を行った場合、主生成物としてGP $\alpha$ の 4 位にマルトリリオルル転移した $p$-nitropheny $1 \alpha$ mal totetraosideと小量の 3 位に転移した $p$-nitoropheny $13^{1}-0-\alpha$-maltotriosyl- $\alpha$ glucosideを供与体基質に対してそれぞれ $15.3 \%$ と 1.1\%の収率で得ることができた。

受容体基質として $\beta$-グルコシドである $p$-nitrophenyl $\beta$-glucoside（GP $\beta$ )あるいは 0 chloro-p-nitrophenyl $\beta$-glucoside（GC $\beta$ )を用いた場合では、受容体基質の4位にマルト忉 シ転移した生成物ばかりでなく、3位に転移した構造異性体が生成し、長時間反応を行うこ

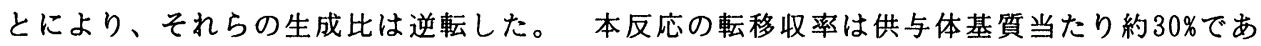
った。 また吡オースを受容体基質とした場合には，七叱オオースの非還元末端側グルコースの4位の みにマルトトリオル転移した。

以上のように、本酵素を用いた転移反応の場合、転移生成物の位置選択性は、受容体基 質のアグリコン配向およびその極性に大きく影響されることを見いだした。

1) T. Usui et al., Carbohydr. Res., in press.

$\mathrm{Ba}-4$

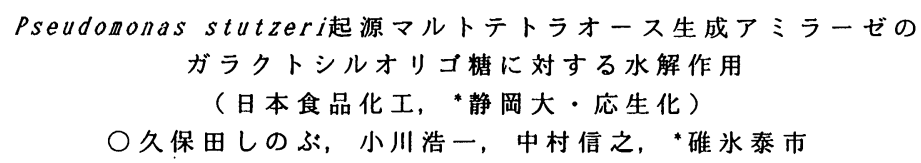

【目的】演者らはすでに、Pseudomonas.stutzeri起源マルトテトラれース生成アミラーゼを （G4生成了ミラーゼ）用いた $p$-nitrophenyl 4-O- $\beta$-D-galactosy1- $\alpha$-maltooligo

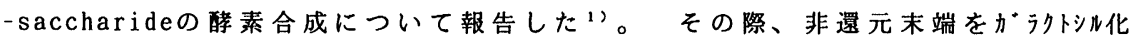
したマルトオリゴ桾を糖転移反応の供与体基質として用いた時、その重合度によって転 移物の生成比率が異なる事を明らかにした。今回は、重合度を異にするがラクト ルマルトオリコ・糖に対する同醉素の加水分解様式について検討したので報告する。

【方法】Bacillus circulans起源 $\beta$-D-ガラクトシダー゙の糖転移反応を利用して、 ラクトースを供与体基質、マルト杖・糖を受容体基質としてマルト杖・糖の非還元末端グルコー 残基にガラクトル基を導入した。次いでその反応液中のマルトオリコ糖をグルコアミラーゼで 水解した後、Toyopear1 HW-40Sを用いて精製して得られる一連のがラクトシルマルト杪ゴ 糖（Ga1-G4〜Ga1-G7）を基質として用いた。 また、G 4生成アミラーゼは、漖粉吸着、 DEAEトヨパール、セファクリルS-200で精製して得られた電気泳動的に単一な標品 を用いた。反応生成物の定量はShodex RS-pak DC-613を用いるH P L C 法にて 行なった。

【結果】マルト放ゴ糖を基質として用いた場合、G 4生成アミラーゼは糖の重合度に かかわらず、それらの切断部位は一定であったか、非還元末端を $\beta$-Dーがラクトッ残 基で修飾してあるガラクトシルマルト归ゴ糖を基質にした場合は、それらの重合度によっ て切断部位が異なる事が示唆された。

1)1992年度日本激粉学会大会講演要旨 
Ba-5 2 次元薄層クロマトグラフィーによるArthrobacter globiformis T 6 イソマルトデキストラナーゼ( G $2 \mathrm{Da}$ a e ) の転移反応の解析

(東京農工·応生科) ○金然桂, 久保直樹, 藤本大三郎, 坂野好幸

[ 目的]A. globiformis T 6 の生産するG 2 D a s e はデキストランを加水分解する 時, 分解物イソマルトースの他に,イソマルトシル基転移反応産物(イソマルトテトラオ 一スなど)も生成することを S a waiら1) は報告している。演者らはG2 Das a グル コース、イソマルトースの他にマルトース、ショ糖、トレハロースなどの糖類及び第 1 級アルコール（メタノール、エタノールなど）にもイソマルトシル基をよく転移するこ とを見い出し、その反応の解析を 2 次元薄層クロマトグラフィー（ TL C ）で行った。

[方法]実験に用いたA，globiformis T 6 の G 2 D a s e S e p h a d ex G-100による アフィニティクロマトグラフィーで精製し、S D S - P A G Eで単一なバンドを示す標品を 用いた。 G 2 D a s e の転移反応は、7\% 糖類（グルコース、マルトース、ショ糖、ト レハロースなど) あるいは $35 \%$ 第1 級アルコール(メタノール、エタノールなど) の 存在下で、 $5 \%$ デキストラン（平均分子量： 3000 ）に G $2 \mathrm{Dase}$ を $300{ }^{\circ} \mathrm{C}$ で作用させ、 転移生成物を追跡した。 反応物の検出はT L C プレート（シリカゲル60F254 S) で1 次方向に展開後、 G $2 \mathrm{D}$ a s e t T L C プレート上で作用させ， 2 次元方向に展開後、 $5 \%$ 硫酸一メ夕ノールを噴霧・加熱し発色させて行った。

[ 結果] A. globiformis T 6 G 2 Da s e の糖類及び第 1 級アルコールの受容体へ の転移は効果的であった。その転移生成物を 2 次元 T L C により解析した結果、主転 移生成物は G 2 D a s e の作用により、再び用いた受容体とイソマルトースに分解される ので $\alpha(1 \rightarrow 6)$ 結合の転移物であると思われた。 T L C の移動度の異なる副生成物 も D 2 D a s e の作用により、主転移生成物からの分解物と同じ分解物を生成した。これ は G 2 D a s e の転移作用により $\alpha(1 \rightarrow 6)$ 結合の他の結合も生じたことを示す。第 1 級アルコール ( $35 \%$ ）存在下の酵素反応でも，G 2 D a s e は受容体アルコールにイ ソマルトシル基を転移することが認められた。

1) T. Sawai and Y. Niwa, Agric. Biol. Chem., 39(5), $1077(1975)$

Ba-6 ミッバチ $\alpha-$ Glucosidase I の活性部位の構造

一 Conduritol B epoxideの標識部位および修飾反応機構の解析一 (北大・応用生命科学) ○木村淳夫、千葉誠哉

[目的] Conduritol B epoxide(CBEと略)は $\alpha$-Glucosidaseの自殺基質である。我々は 本酵卖をCBEで修飾し、失活がMichael is中間体経由で生じ、触媒部位にCBEが結合すること

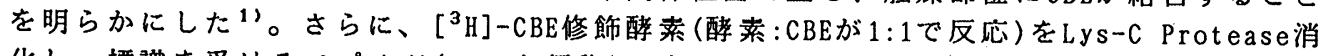
化し、標識を受けるぺプチド(LY15と仮称)の全一次配列を決定した ${ }^{21}$ 。今回、CBE標識部位 を決定するととすに、修飾反応機構を解析したので報告する。

[方法、結果] CBE処理酵䒺からのLY15を気相シークエンサーで解析すると8番目のAsp $\left(D^{8}\right)$ 以降の配列が解析できなかった。このLY15を NH2 OH処理すると、 ${ }^{8}$ 以降の解析が可能と なった。 $\mathrm{I}^{7}$ (7番目のIle)と $\mathrm{D}^{8}$ 間はAsp-N Proteaseにより切断できないこと(CBE処理しない 酵卖のLY15は $I^{7}-D^{8}$ 間が切断された) から、 $D^{8}$ なBEが修飾し、その立体障害でProteaseが作 用できないと考えられた。従って、CBEはLY15のD 8 を特異的に標識し、これが本酵素の触媒 基の一つであると推定した。 $D^{8}$ とCBEの反伈機構を調べるため、CBE修飾酵素をHC1処理して 得た水解物 (TMS化する)をGLC分析した。 scyl10-Inositol(sIと略)のピークが認められ、そ のGC-MS分析の結果す標品と一致したので、 $D^{8}$ がCBEのC-2を求核攻撃し、sIとのエステルを 形成すると推定した。なお、加熱失活酵素をCBE処理し、同様な分析をしたが、SIが認めら れないことからCBEは酵索活性を有する蛋白のみを修飾することが判明した。

我々は $\alpha-G 1$ ucosidaseがその構造情報から少なくとあ二つのグループに分類できると考

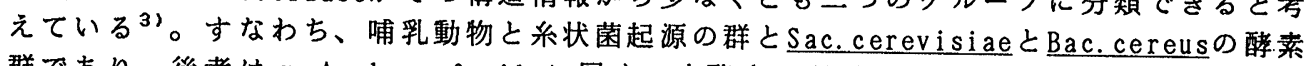
群であり、後者は $\alpha-A m y l$ ase familyに属す。本酵素の配列については約60\%が決定され、 相同性から後者に分類でき、今回推定した触媒基D ${ }^{8}$ は Taka-amylase AのAsp 26 に相当する。 本研究は $\alpha$-Amylase familyの活性部位を自殺基質を用いて解析した初めてのあのである。 1) 農化, 64, 415(1990). 2) 農化, 67,365(1993).3)第15回糖質シンポジゥム, 印刷中 (1993). 
Ba-7 テンサィ $\alpha$-Glucosidase $の$ 活性中心のアミノ酸配列の決定 (北大·農) ○岩波俊介、木村淳夫、伊藤浩之、森春英、松井博和、 本間守、千葉誠哉

[目的] テンサイ $\alpha$-Glucosidaseは、エキソ様式に $\alpha$-グルコシド結合を加水分解し、反応生成 物として $\alpha$-グルコースを遊離する酵素である。我々はすでに本酵素について反応速度論的解 析 $^{1)}$ 、水溶性 Carbodiimideおよび親和標識試薬である.Conduritol B e poxide(CBE)を用いた化学修 飾法により、触媒反応にはカルボキシル基が関与していることを確認した。本研究では、本 酵素遺伝子の単離と一次構造の解析を目的とし、まず、CBEを指標として、プロテインシー ケエンサーにより活性中心およびその近傍のアミノ酸配列を決定した。また、その情報にも とづいて、本酵素をコードする cDNAの一部をPCR法により增幅し、解析したので報告する。 [方法およひ桔果]本酵素は既報の方法で精製した ${ }^{2)}$ 。CBEは $\alpha$-Glucosidaseの自殺基質であ り、活性中心に特異的に取り込まれ、活性触媒基と共有結合を形成する。電気泳動的に高度 に精製された本酵素をCBEで処理すると $\left(\mathrm{pH} 4.5,37^{\circ} \mathrm{C}\right)$ 、擬一次的に活性の減少が認められた。 この失活反応は複合体経由のものであり、酵素1分子あたり1分子のCBEの結合によることが わかった。また、本酵素のCBE処理後、還元ピリジルエチル化を行い、Lys-C protease消化し た。得られたペプチド断片を逆相HPLCで分離し、配列解析を行ったところ他の $\alpha$-Glucosidase と相同性の高い領域に含まれるAspにCBEが結合していることを認めた。一方、テンサイ溸濁 培養細胞からcDNAを合成し、これを鋳型として上記配列を含む幾つかのアミノ酸部分配列を もとに作成したオリゴヌクレオチドプライマーを用いてPCRを行った。現在、增幅したDNA 断片 (約 $500 \mathrm{bp}$ )の解析を行っているところである。

1) H.Matsui and S.Chiba, Agric. Biol. Chem., 45,141(1981).

2) S.Chiba et al., Agric. Biol. Chem., 42, 241(1978).

Ba-8 トラマメ（Phaseolus vulgaris L. cv Toramame） $\alpha$-amylase cDNAのクローニング とシークエンス（北大・農・生物機能化学、*応用生命科学） ○小林 哲也、

*森 春英、殿川 隆志、伊藤 浩之、松井 博和、本間 守、*千葉 誠哉

（目的）植物の $\alpha$-amylaseはイネ科およびマメ科などの多くの発芽種子より精製され、 発芽期におけるその生産の制御機構について報告されている。近年、コムギ（1987） い、 イネ（1990） 2)において、登熟中にも認められる $\alpha$-amylase活性は、発芽期とは異なる夕 ンパク質によるものであり、それらの遺伝子解析がなされている。我々は上記二例とは独

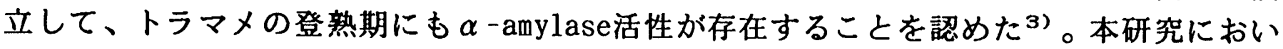
ては、登熟期と発芽期に発現する $\alpha$-amylaseの遺伝子レベルにおける異同を調へ、本酵素 の部位特異的および時期的発現様式の解析を目的として、発芽子葉より $\alpha$-amylase cDNAの クローニングを行ない、塩基配列の解析を行なった。

（方法及び結果）トラマメ発芽6日目の子葉よりSDS-フェノール法でRNAを抽出、poly (A) ${ }^{+}$RNAを得た。このmRNAを鋳型としてcDNAを合成し、入gt11に組み込んでライブラリーを 構築した。精製 $\alpha$-amylaseの部分アミノ酸配列および Hung bean $\alpha$-amylaseの cDNAの塭 基配列をもとにして合成したプライマーによりPCRを行い、約600bpのDNA断片を得た。これ をプローブとしてライブラリーのスクリーニングを行った結果、約 $1.4 \mathrm{kbp}$ 挿入断片をも つ陽性クローンが得られた。この塩基配列を解析をしたところ、この $1.4 \mathrm{kbp}$ 断片は $\alpha$ amylaseの0RFを完全に含んでいることが明らかになった。現在、全長 cDNAの塩基配列を確 認中である。

1 ) David C. Baulcombe, et al. , Mol. Gen. Genet., 209, 33(1987)

2 ) Ning Huang, et al. , Nucl. Acids Res., 18, 7007(1990)

3 ）農芸化学会大会要旨、1990（京都） 
Ba-9 Penicillium purpurogenum由来 endo-inulinase cDNAのクローニンク ( 酪農大·食品化学、“北大·生物機能化学、“北大·応用生命科学)

○思上豊隆、小野寺秀一、塩見徳夫、“伊藤浩之、“森春英、“条村淳夫、

・松井博和、・本間守、“葉誠哉

〔目的〕 Penicillium purpurogenumの生産するendo-inulinaseはイヌリンをランダムに 加水分解し生成物としてイヌロオリゴ糖を遊離する菌体外醉素である。我々は、すでに本

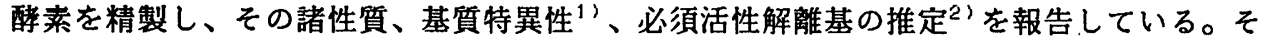
こで本研究では endo-inulinaseの一次構造の解析を行うことを目的として本酵索をコード する遺伝子のクローニングを行った。

〔方法及び結果〕 既報の方法”により精製した醉素標品をりジルエンドペプチターゼによ り消化し、HPLCにより分離、回収した数種のペプチドのアミノ酸配列をプロテインシーヶ ンサーにより決定した。これらのアミノ酸配列に基づいてオリゴヌクレオチドプローブを 合成し、P. perperogenumより作製したcDNAライブラリー（入gt11）をスクリーニングした。 得られた陽性クローンに挿入されたCDNA（1300bp, EI-1）をプラスミドベクターにサブクロ ーニングし塩基配列を解析した。その結果、EI-1cDNAは endo-inulinaseの N末端を欠く全 体の約 $80 \%$ をードしていた。そこで、EI-1cDNAをプローブとして、再度作製したCDNAラ イブラリー（ $\lambda \mathrm{gt} 10 ）$ をスクリーニングしたところ、4つの陽性クローンが得られた。こ れらクローンに㨉入されたcDNAは、制限酵素地図及び一部の塩基配列より、いずれす同一 であると考えられた。そこで、これらのうち 1 つをEI-2cDNA（1700bp）とし、その塩基配 列を決定した（全長の約70\%）。塩基配列より予想されるアミノ酸配列中には、本酵素の $\mathrm{N}$ 末端からC 末端までが含まれていることが推定された。また先に決定したアミノ酸部分 配列は、すべて含むことが確認された。現在、全塩基配列を決定中であり、また、本酵素 遗伝子の大腸菌での発現及びゲノミッククローンの単離を行っている。

1) Onodera \& Shiomi,A.B.C., $\underline{52}, 2569(1988)$. 2)小野寺ら,農化大会要旨 66 , 355(1992).

Ba-10 Arthrobactor globiformis T6の isomalto-dextranase 遗伝子のクローニングと大腸菌での 発現（北大·農、*静岡大·教育）○伊藤浩之、岩井淳、水野隆文、

森春英、松井博和、本間 守、千葉誠哉、 $*$ 岡田唓太郎

[目的] Arthrobactor globiformis T6は、土壤中に生育するコリネ型細菌の一種であり、isomaltodextranase (EC 3.2.1.94) を生産することが知られている(1)。本酥素は dextran の非還元末端より 2

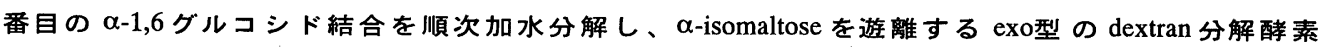
である。本酵素の精製および基啠特異性などについてはすでに報告されているが(2)、その構 造や反応機構についてはほとんど明らかにされていない。本研究では、これらを分子レベル で解明することを目的に、isomalto-dextranaseをコードする遗伝子を単離し、その構造を解析し た。また、本酵素のタンパク的改変を行うため、大腸菌内での発現を試みたので報告する。 [方法およひ結果] 本酵素の精製標品から気相プロティンシーケンサーを用いて決定したア ミノ酸部分配列をもとに、オリゴヌクレオチドプローブを合成し、A. globiformis T6の染色体 DNAより作製した遗伝子ライブラリー ( ンの挿入 DNA断片 $(12 \mathrm{~kb})$ のサイズを限定し、約 $3.5 \mathrm{~kb}$ の Pst I 断片をプラスミドベクターにサ ブクローニングし、塩基配列を解析した。本酵素遭伝子のオープンリーディングレームは

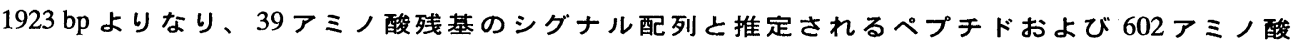
残基の成熟タンパクをコードしていた。isomalto-dextranaseタンパクを大腸菌内で誘蓄発現させ るために、本酵素遗伝子を pUC18ベクターのlac プロモーター下に組み込んだプラスミドを作 製した。このプラスミドにより形質転換された大腸菌をIPTG存在下で培蕃し、菌体内の酵素 活性を測定したところ、培養夜 $1 \mathrm{ml}$ あたり $0.23 \mathrm{U}$ の isomalto-dextranase 活性が検出された。また、 発現したタンパクを SDS-PAGE後、isomalto-dextranaseに対する抗体を用いて western blotting 法に より確認した。現在、さらに高発現の宿主ーベクター系を検討中である。

$\begin{array}{ll}\text { 1) T. Sawai et al., J. Biochem., 75, } 105 \text { (1974) } & \text { 2) G. Okada et al., Agric. Biol. Chem., 52, } 829 \text { (1988) }\end{array}$ 
Ba-11 ブタ腎臟 aldose 1-epimerase（mutarotase）cDNA のクローニングと大腸菌 での大量発現 (北大・応用生命科学, “北大・生物機能化学)

○森 春英, 北澤 暁, “伊藤浩之, 木村淳夫, 千葉誠哉

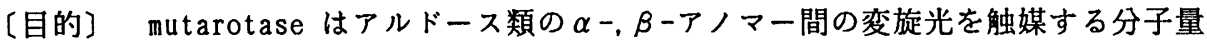
約 37,000 の単量体からなる酵素である。我々は既に本酵素の作用により glucoamylase の縮合反応を低下できることを明かにし”、これにより現行の澱粉からの glucose 生産 の収率を向上できる可能性を見いだした。本報告では、mutarotase の利用ならびに触媒 反応機構や活性部位の推定の基盤となる mutarotase cDNA のクローニングと 大腸菌での 高発現系の構築を行なったので報告する。

〔方法および結果〕プロテインシーケンサーにより明らかにされた本酵素の部分アミ ノ酸配列に相当するオリゴヌクレオチドを合成した。これをプローブとして、ブタ腎臓か ら作成した cDNA ライブラリー（入gt10）よりスクリーニングを行なった結果、約 7 万株 より $5 つ の$ 陽性クローンが得られた。これらの挿入断片長および部分塩基配列より、本酵 素をコードすると推定された約 $1.4 \mathrm{~kb}$ の挿入断片を pBLUESCRIPT にサブクローニングし、 全塩基配列を解析した。その結果、この cDNA は mutarotaseの ORF 全域を含むと予想さ れ、推定了ミノ酸配列は既報2)の本酵素の配列に完全に一致し、リーダー配列は認められ なかった。酵菜の発現には、発現ベクター pTrc99A の trc プロモータ制御下に mutarotase cDNA を組み込んだものを使用した。このプラスミドを導入した大腸菌 JM109 形質 転換体を LB で培養したところ、菌体内に大量の mutarotase が発現した。その分子量は SDS-PAGE でブタ腎蔵からの精製酵素と同じ約 37,000、推定蛋白質量は大腸菌の全蛋白質 量の約 $22 \%$ 、活性は培養液 $1 \mathrm{ml}$ 当たり約 $33.8 \mathrm{U}$ を示した。また、プロテインシーケンサ 一により、発現蛋白質の約 $30 \%$ N末端に Met を有することが明らかになった。

1）木村，千葉，澱粉科学，37，206（1990)，2)北澤ら，農化誌，66，344（1992）. 
Bp-1 Irpex lacteus のセルラーゼ系に関する研究（第 9 報） アビセル糖化型セルラーゼ 2 成分の比較

(静岡大・教育) 岡田嚴太郎, ○金井 健

【目的】白色腐朽菌I I pex lacteus は複数のセルラーゼ成分からなるセルラーゼ系を構 築している。我々はすでに, 当該菌の市販セルラーゼ製剤から高純度に精製されたアビセ ル糖化型セルラーゼ II-1-aについて, その特性解析を行い報告した ${ }^{1.2)}$ 。今回は, 本セル ラーゼ製剤中に存在する新規アビセル糖化型セルラーゼ II -1- - $_{1}$ の精製法, 精製酵素の示 す基本的な性質や基質特異性などを精查し，これらを既報のセルラーゼ П-1-aで得られた 結果と相互に比較・検討することを目指した。

【方法】協和発酵工業(㑛製市販セルラーゼ製剂（ドリセラーゼ）を用いて, Amberlite CG-50, CM-TOYOPEARL 650S, DEAE-TOYOPEARL 650S などのイオン交換クロマトグラフィー やBio-Gel P-100などのゲル滤過を適宣組み合わせ，当該䣲素を高純度に精製した。酵素 反応の結果生成されるグルコース，還元糖はそれぞれグルコスタット法, Somogyi-Nelson 法を用いて比色定量した。

【結果】精製酵素はNative-PAGEおょびSDS-PAGEで, それぞれ単一のタンパク質染色バ ンドを与える高純度標品であった。当該醅素の分子量は約 50,000(SDS-PAGE法)，糖含量 （グルコース換算）は 4.3\%，アビセルに対する比活性值は $0.027 \mathrm{U} / \mathrm{mg}$ protein であっ た。本䣼素はセルラーゼ II -1-a と同様, 高濃度で高濃度のセロビオースに比較的長時間作 用させると, 単なる加水分解反応によらないで, 多量のグルコースを生成した。本酵素の 基質特異性ならびに作用特性などについても報告する。

1) 岡田, 金井, 山崎: 澱粉科学 第39巻 第3号 p. 241 (1992).

2)岡田, 金井, 山崎：日農化誌 第67巻 第3号 p. 122 (1993).

Bp-2 Irichoderma virideのセルラーゼ系に関する研究（第33報） セルラーゼII -bの示すグリコシレーション作用

(静岡大・教育) 岡田嚴太郎, ○神原秀晃

【目的】我々はすでに, 系状菌 Trichoderma viride $の$ 構築するセルラーゼ系構成メン バーのうち, 天然セルロースの糖化に主役を演ずる key enzyme はセルラーゼ II -bおよび III であることを報告した ${ }^{1,2)}$ 。本報では，セルラーゼ II -bの示す特異なグリコシレーショ ン (水解・縮合・糖転移) 作用を総合的に解析し, 当該酵素が $\underline{\text {. viride }}$ のセルラーゼ系 中で果たす主要な役割について考察した。

【方法】 $\beta$-グルコシダーゼ活性を全く示さない高純度セルラーゼ II-bの調製は既報 ${ }^{3)}$

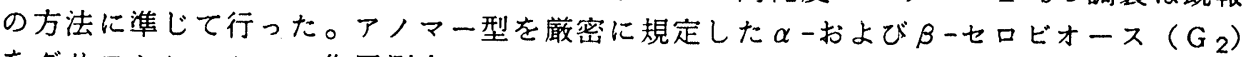
をグリコシレーション作用測定のドナ一基質に用いた。酵素反応の結果生成されるグルコ ース $\left(\mathrm{G}_{1}\right)$ は，グルコスタット法により比色定量した。

【結果】(1)セルラーゼII -bは $\beta-G_{2}$ を特異的に利用して, 短時間内に多量の $G_{1}$ を生成 し, 初期反応曲線はエクスポネンシャルな様相を呈した。（2）本 $G_{1}$ 生成における $\beta-G_{2}$ の最適濃度は約 $120 \mathrm{mM} ゙$ あた。（3）セルラーゼ II -b vs. $\beta-\mathrm{G}_{2}$ による $\mathrm{G}_{1}$ 生成曲線は典 型的なシグモイド型を示した。(4)セルラーゼII-b vs. $\beta-G_{2}$ の反応系に少量のセロトリ オースあるいはセロテトラオースを添加すると, 反応曲線はシグモイド型から Michael is -Menten 型に移行した。（5)各種のデータを総合するとセルラーゼII-bは特異なグリコシ レーション作用により， $\beta$-グルコシダーゼの関与なしに高効率でセロビオースのグルコ ース化に寄与することが明らかになった。

1) 岡田, 田中: 澱粉科学 第 35 巻 第 4 号 $253 \sim 277(1988)$, 2) 岡田: 澱粉科学 第37巻 第4号 287〜298(1990),3) G.0kada \& Y. Tanaka : Agric. Biol. Chem., 52,617 619(1988). 
Bp-3 エキソ型セルラーゼの水溶性基質に対する反応性と特異性

（信州大・工）○城石雅弘、天野良彦、神田䳡久

（目的）先に我々は、I.1acteus、I. reesei、年. niger由来のエキソ型セルラーゼを高度に 精製し、結晶化度（CrI）の異なるセルロースに対する形態的観察及び特異性を比較検討し、 また、これらエキり型醉素間の相乗作用についても一部報告した セルラーゼは結晶性セルロースに対して主に G 型セルラーゼとの組み合わせにおいてのみ顕著な相乗作用が認められた。その水解生成物 は主にG $G_{2}$ あった。今回は、セロオリコ糖及び合成基質などの水溶性基質に対するこれら エキソ型セルラーゼの水解举動、及び基質特異性について比較検討した。

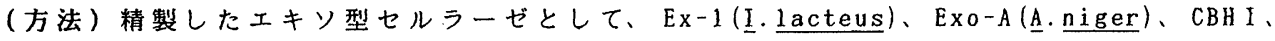
CBH II (T.reesei)の 4 種を用い、水溶性基質としてセロオリゴ糖、p-nitropheny1配糖体、 4-Metylumbel1ifery1配糖体及び染料基質（OBR-HEC、RBB-X）を用いた。水解生成物は、 T L C、H P L C、及び比色法により定性、定量した。

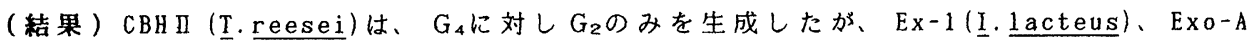

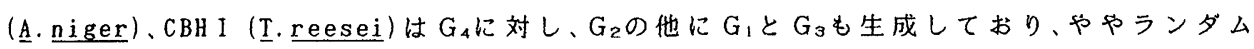
的な水解を示した。また合成基質に対して CBHII は、非還元末端㑡からセロビオース単位で 作用するが、Agluconic bond には全く作用せず、これら基質に対して特異性が籗密である のに対し、他のエキソ型セルラーゼ、すなわちEx-1、Exo-A、CBHIは、セロビオース単位での 認識性が高分子基質と比較して䁔昧になる傾向がみられた。またこれら䣼素はAgluconic bond 亿全て作用し、CBHII とは異なる基質特異性を示した。

1 ）神亩与：譨化大会講演要旨集 P. $2443\left(\begin{array}{llll}1 & 9 & 9 & 2\end{array}\right)$

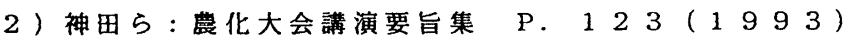

Bp-4 Aspergillus niger $\beta-$ g lucosidaseの分子機構 グルカノー1:5-ラクトン結合反応の平衡論的研究 （京府大・農化、*静岡大・教育） O矢崎晃隆、*岡田綮太郎、大西正健

近年、グリコシダーゼが注目を集めているが、我々は $\beta$-glucosidaseを取り上げること とした。本酳素は食品素材づくりなどに極めて有用である。しかし、触媒する反応の分子 㯕構はそれほど解析されていない。そこで、蛍光変化を指標としてりガンドのとり込み反 态を钼测し、その機構を平衡論的に解析しようとした。

〈実験材料と方法〉酵素標品は、粗酳素製剤Novozym 188 （ノボノルディスク社製）を 遠心した後、陰イオン交換クロマト（DEAE-TOYOPEARL 650M）、疎水クロマト（Butyl-T0

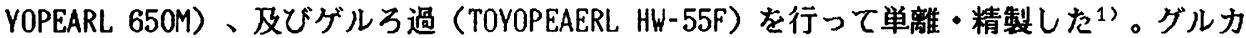
ノー1:5-ラクトン（以下グルカノラクトン）は和光純薬の製品をそのまま使用した。蛍光変 化（励起280nm、310nmに透過率の半値を有するフィルター）は、photal（大塚電子）社の 高速反応装置（光源、150W重水素ランプ）を用いて観測した。䣼素触媒活性の測定には、 $\rho$-Nitrophenyl $\beta$-glucoside $(\beta-\rho \mathrm{NPG})$ ならびにセロビオースを基質として用いた。実験資 料の解析と評価は京都ソフト社のパソコンソフト『バイオグラフ』に依った。

〈実験結果〉 上記各技法により精製して得た最終酵素標品は平板ゲル電気泳動で単一の バンドを示した。酻素の T r p 残基に基づく虽光を指標として、グルカノラクトンの取り 込み反応を観测（醉素濃度； $2 \mu \mathrm{M} 、 25^{\circ} \mathrm{C} 、 0.02$ M酢酸緩街液 $\mathrm{pH} 5.0$ ）した結果、グルカ ノラクトンは本酵素に強く取り込まれることが判明した。蛍光滴定から求めた平衡論量は、 $\mathrm{Kd}=0.38 \mathrm{mM} 、 \Delta \mathrm{F}_{\max }=30 \%$ \%であった一方、本酵素の最適基啠であるセロビオース を用いる触媒活性の測定技術を開発し、グルカノラクトンによる阻害機構を調べ、蛍光観 測の結果と比較して、リガンド取り込みの分子槽構を解析した。

文献 1) 岡田敞太郎ほか(1992)、日農化誌、66、504 
Bp-5 Arthrobacter globiformis I42のグルコデキストラナーゼに関する研究 （第 7 報）精製醅素の示す触媒特性 (静岡大・教育) 岡田嚴太郎, ○杉浦 哲

【目的】グラム陽性土壤細菌 Arthrobacter globiformis I4 2 の産生するグルコデキス トラナーゼ(GDase, EC 3.2.1.70) はデキストラン分子を加水分解し, その非還元性末端か ら順次 $\beta$ ーグルコースを生成するグルコアミラ一ゼ型の醉素である。我々はすでに，当該 酵索の簡易精製法・基本的性質1)ならびに精製醉素が併有するグルコアミラーゼ活性 2)な どについて報告してきた。今回は, 精製醉素が示す特異な縮合・糖転移作用を詳細に解析 した結果について報告する。

【方法】高純度GDase の調製は既報1)の方法に準じて行った。アノマー型を厳密に規定 した $\alpha$ ーおよび $\beta$ ーグルコースをドナー基質に用い，当該酵素の示す縮合・糖転移反応を 解析した。反応生成糖の検出・同定・定量にはPPC, TLC, HPLCなどを適宜使用した。

【結果】（1）精製 GDaseは $\alpha$ 一あるいは $\beta$-グルコースのいずれをす利用して，イソマ ルトースを生成するというユニークな触媒特性を示した。(2) 高濃度酵素 (16 unit)を用

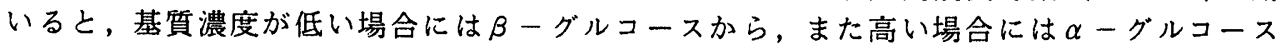

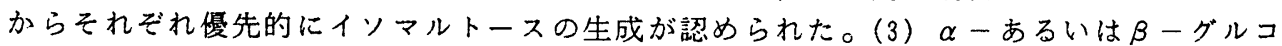
一スそれぞれから生成されるイソマルトース量が一致する基質濃度はおよそ15\%(w/v) と 判明したが, 両イソマルトースの生成過程は相互に異なるむのと推察された。(4) 各種の 実験データを総合すると, GDase は縮合反応には $\beta$-グルコースを, また糖転移反応には $\alpha$ ーグルコースをそれぞれドナ一基質として利用するすのと考察された。

1)G. Okada, T. Unno \& T. Sawai : Agric. Biol. Chem. , 52, 2169 2176(1988).

2)G. Okada \& T. Unno: Agric. Biol. Chem., 53, 223 228 (1989).

Bp-6 Schizosaccharomyces pombe 菌体外分泌 $\alpha$-Glucosidase に関する研究

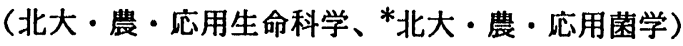

○谷本佳博、木村淳夫、*横田 篤、千葉誠哉

〔目的〕我々は既にSchizosaccharomyces pombeの菌体内 $\alpha$-glucosidaseの諸性質を明 らかにした"。本酵素の一次構造を含めた構造情報を解明するには、大量調製法の確立が 必要となる。菌体取得のため液体培養を行なったところ、培地中にす $\alpha-g 1$ ucosidaseが分 泌されることを認めた。今回、この分泌䣼素に焦点を絞り、培養条件を詳細に検討した。 その結果、合成培地を用いて高分必条件を決定できたので報告する。

〔方法および結果〕本囷を1\%酵母エキス、2\%ポリペプトン、2\%水飴（市眅品）からな る培地 (YPD) で振とう培養をし、培養上清に $\alpha-g 1$ ucosidase活性が認められた $(0.15 \mathrm{U} / \mathrm{m} 1)$ 。 この際、 $\alpha$-amylase活性は確認できず、glucoseからmal topentaoseまでのオリゴ糖が資化 され、これ以上の重合度のものは、生育が終了しても培地中に残存することが認められた。 YPDでは培地成分由来の夾雑蛋白により、本酵素の精製自体が困難になると考えられた。一 方、本菌については合成培地（EMM, 炭素䃇はglucose）が知られている2)。、これを用いて 培養を行ったところ菌体の最終生育量がYPDの約4割であった。そこでEMMの微量成分以外の るのを2倍の濃度にした培地 (E2)を用いてYPDと同様の生育を得た。次に、炭素源について 検討した。glucoseおよびmal toseの場合には培地中に $\alpha$-glucosidase活性が認められず、

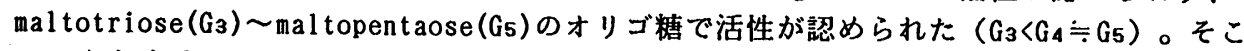
でG5を主成分としたオリゴ糖（G5:約70\%）を用いて培養を行い、YPDの約2倍の活性を得た。 培地pHの低下が認められたのでMES (2-(N-morpholino)ethanesulfonic acid) 緩衝液を用 いて $\mathrm{pH}$ の低下を緩和したところ培養液 $1 \mathrm{ml}$ 当り $0.85 \mathrm{U} / \mathrm{ml}$ となり、YPDの約 6 倍の酵菜活性を得 る条件を決定した。現在、菌体外醉素を精製中である。1)S. Chiba \& T. Shimomura, Agric. Biol. Chem. . 29. 540 (1965). 2) J. M. Mitchi son, Methods in Cell Physiol. . 4. 131(1970). 
Bp-7 Nーブロモサクシンイミド（N B S ）によるホスホリラーゼの化学修飾 （鹿児島大・生物資源化学）○菅沼俊彦, 竹下正彦, 北原兼文, 永浜伴紀

【目的】ポテトホスホリラーゼの活性中心近傍の T r p 残基の役割を探る目的で T r p 残基の修飾剤である N B S を作用させ、得られた修飾醉素の特異性の变化を調べた。

【方法】保護剤としてマルトトリオース存在下で化学修飾するのと、保護剤なしの条件 で化学修飾するのと 2 種の修飾醉素（P醉素と M 䣼素）を調製し、それぞれについてクル カン合成反応における可溶性溉粉（片山化学）とG1 P の速度パラメータ（Km, V) を決 定し未修飾䤃素（I 䣼素）のものと比較した。また、それぞれの䣼素の活性化エネルキーー も求めた。

【結果】I䤃素の活性を 100 とすると $\mathrm{P}$ 醉素とM醉素はそれぞれ 75 と 54 になった。 クルコースの保護効果は弱かった。下表に示すように $\mathrm{K} m$ に対する影響は可溶性溉粉に対し ては M 醉素はI 醉素に比べその值が約 3 倍大きくなった。一方、P 醉素は I 醉素とほほ近 い值となった。すなわち、M醅素ではマルトトリオースの結合部位近傍に修飾された残基 があり、それが可溶性澱粉の親和性に影響したことが示唆された。興味深いことに G $1 \mathrm{P}$ に対しては M醉素の方が I 䤃素より $\mathrm{K}_{\mathrm{m}}$ の值は $60 \%$ とさくなり、上記残基の修飾が見か け上G $1 \mathrm{P} へ$ の親和性を少し高める結果になった。しかし、いずれの修飾醉素もI 䣼素に 比べ Vの值が小さくなり、また、 活性化エネルギーも大きくなった ので触媒活性自体が隇少したこと が分かった。

\begin{tabular}{|c|c|c|c|c|c|}
\hline & $\begin{array}{c}K_{m} \text { va } \\
\text { S.Starch } \\
\left(x_{0}\right)\end{array}$ & $\begin{array}{l}\text { ue } \\
\text { G-1-P } \\
(m M)\end{array}$ & $\begin{array}{c}V_{\max } v \\
\text { S.Starch } \\
(\mu \mathrm{mol} / \mathrm{m} \ln ) \\
\end{array}$ & $\begin{array}{c}\text { ue } \\
\text { G-1-P } \\
(\mu \mathrm{mol} / \mathrm{m} \mathrm{m})\end{array}$ & $\begin{array}{c}\text { Activation } \\
\text { Energy } \\
\text { (kcal) }\end{array}$ \\
\hline Intact & 0.02 & 2.0 & 0.081 & 0.12 & 6.26 \\
\hline Modified & 0.06 & 1.2 & 0.032 & 0.036 & 7.50 \\
\hline Protected & 0.027 & 1.7 & 0.039 & 0.054 & 7.96 \\
\hline
\end{tabular}

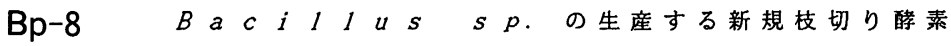
(天野製薬)

○过廣二、河合美智代、森茂治、廣瀬進、大矢隆一

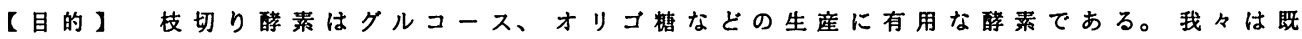

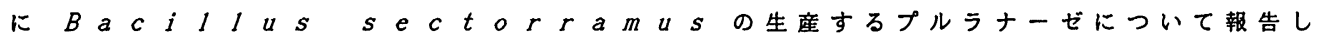

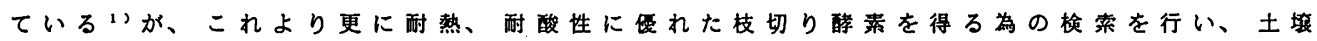
中より新たに枝切り酵素を生産する菌株を得たのて、その菌及び醇栗の性啠について報告 する。

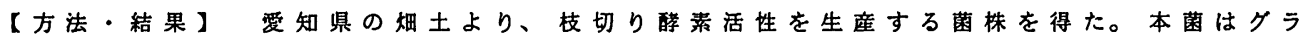
厶隔性で胞子を着生し、好気的に生育することから、Bacilllus 屈に属する菌株

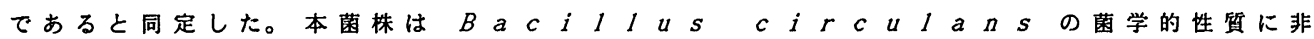
常に類似しているが、カタラーゼ㓌性である点で異なっている。本菌株をワキシースタ一

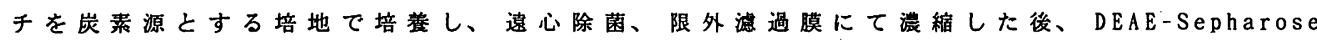
CL-6B， $\alpha$-cyclodextrin-Sepharose, Toyopear1 B/-55S のカラムクロマトにより精 製を行った。精製標品はS D S - P A G E にて単一であった。本菌株の生産する枝切り醉 素の至道 $\mathrm{p} \mathrm{H}$ は $5.0 \sim 5.5$ で、至道温度は $65^{\circ} \mathrm{C}$ 付近にあり、安定 $\mathrm{pH}$ H $4 \sim 6$ 、 温度は $65^{\circ} \mathrm{C}$ まで安定であった。また、本酻素の等電点は2.9 1 、分子量はS D S P A GEにて 98 ，０００菅ると推定された。本醇素はプルランによく作用することか らプルラナ一ゼであると考えられる。しかし、本醉素のプルランに対する各種基質の水解

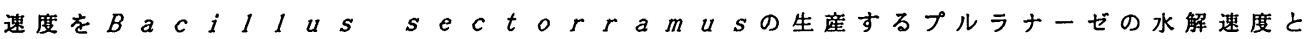
比較した場合、アミロペクチン（トウモロコシ起源）にて2.7 倍、グリコーゲン（カキ 起源）にて 4.4 倍の值を示した。

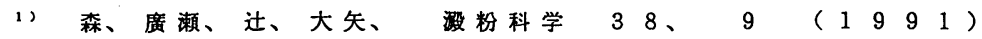


Bp-9 イネsugar y (曹水省・生物研、*果北曹試、**九州農試; $* * *$ 九州大・豊学部) ○中村保典、*梅本貴之、 $* *$ 高姆康浩、天野悦夫、 $* * * *$ 佐藤光)

【目的】テンプン合成代期解析研究においてミュータントの使用は亟めて有効である。 れわれはイネ肧乳におけるアミロペクチン合成機楎を解明するために、 s u g a r y

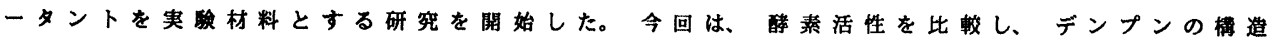
解析を行った結果を報告する。またstarch debranching enzyme（RE）を精製し、c D $\mathrm{NA}$ 塩基配列を解析した結果についても述へる。

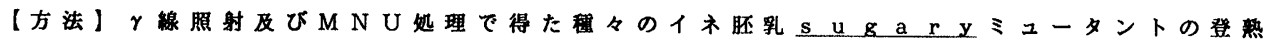

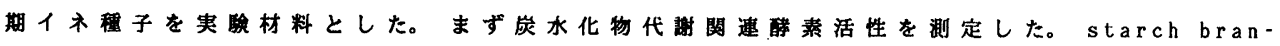
ching enzyme（QE）とREに関しては、native-PAGE/活性染色法でらに調へた。また ミュータント82GF3su2と処理親の曹林 8 号のテンプン分析を行つた。 $\mathrm{R}$ Eを品種フジカ リ登鶖程子から H P L C゙精製し、その c D N A 塩基配列はジデキシ法によって決めた。

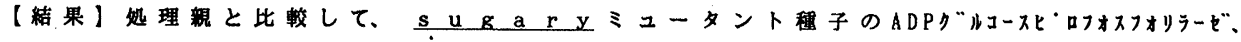
可溶性およびテンプン粒結合型スターチシンターゼ、フォスフォリラーゼ、UDPグルコースヒ・ロフォスフォリラーゼ、スクロー スシンタービ活性には有意な差はないが、 $\mathrm{RE}$ 活性は著しく低かった。ミュータントによって は Q E 活性もかなり低下した。また82 GF3su2のデンプンは親品種のものと大きく異なり、

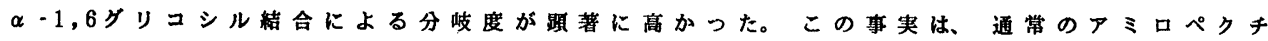
ン合成にはREも閏与しており、 $\mathrm{RE}$ 活性と $\mathrm{QE}$ 活性のバランスが重要な役割を果たして いることを示していると推定した。 REは分子量約 10 万の単量体でToguri ${ }^{1}$ の結果と同

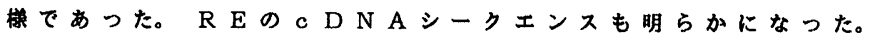

1) T Toguri (1991) J Plant Physiol 137,541-546.

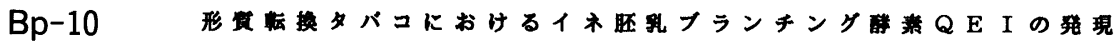

（農水省・生物研）○中村保典、光原一朗、張媇、村上高、大霞祐子

【目的】テンプンフランチング醳素（starch branchingenzye，QEと略記）は一般に等

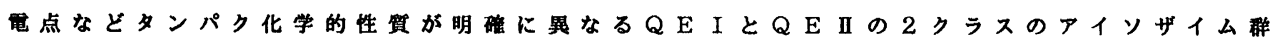
から成るが、その発現は程特異的かつ器官・組織特異的である”。われわれはイネ眼乳に は Q E I、 $\mathrm{Q} E$ II a、 $\mathrm{Q}$ E II b 3 程類が発現していることを明らかにした1)上で、前 2 者の c D N A 棰造を決定している ${ }^{2)}$ 。しかし、各アイソザイム間の機能分担は明礁ではな

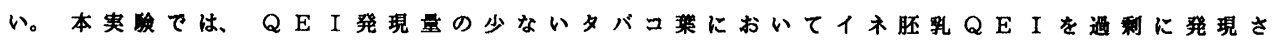
せ、タバク莱におけるテンプン合成に与をる影霞を調查した。

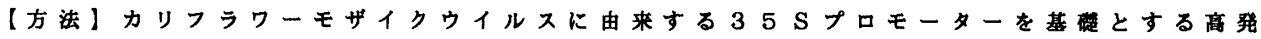
現ベクターにイネQEIのc D N A ココード領域を連結し、アクロバクテリウムを介した 間接道入法により形筫転換タパבを作成・選抜した。その緑葉におけるイネQEIの発現 を調へた。

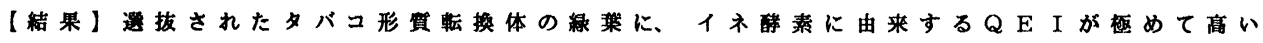
レベルで発現していることが、native-PAGE/活性染色法で示された。またイネQEIの発 現は、ノーザンブット、ウェスタンブロット分析によっても確㑇された。発現している QEIはタバコ染緑体に局在していた。

1) H Yamanouchi \& Y Nakamura (1992) Plant Cell Physiol. $\underline{33}, 985-991$.

2) Y Nakamura \& Hamanouchi (1992) Plant Physiol. 99, 1265-1266. 
Bp-11 Bacillus firmus KT-140産生するC G T a s e の精製及び諸性貿について (大阪薬科大学・第一微生物、※微化研) O森脇将光, 过坊裕, 宮本勝城 ※今田千秋，※岡見吉朗，稻森善彦

[目的]サイクロデキストリンは、食品及び医薬などの応用分野に㧍いて注目されている るのに伴い、種々のC G T a s e が精製され、その諸性質が明らかにされている。

演者らは、既存の酵素とは異なるユニークな性質を有する C G T a s e 産生株を海洋環境 に求めスクリーニングした結果、一株の細菌がC G T a s e を安定に産生することを热好 た。そこで、今四、本菌の廒生するC G T a s e の精製ならびに諸性貿について娭测し太 ので報告する。

[方法] C G T a s e の精製は、培養上清から、DEAE - Toyopearl 650M, Sephadex G-100 及びPhenyl-Toyopearl 650Mカラムクロマトグラフィーにより行った。Cyclization活性は Horikoshiらの方法で行い、Starch-degrading活性はFuwaの方法に準じて測定した。

[結果]海洋微生物から C G T a s e 産生菌のスクリーニングを行った結果、水樑 200 $0 \mathrm{~m}$ の海水より分離された一株が C G T a seを産生すること認めた。そこでまず本菌の㫏 生する C G T a seを電気泳動的に単一まで精製した。また、本菌の諸性筫についても検討 を加え以下に示す結果を得た。

（1）分子量：68 KDa (2) 等電点：4.3（3）至適 $\mathrm{p} \mathrm{H}: 6.0 \sim 7 . \mathrm{O}(4)$ 至適温度：60 ${ }^{\circ} \mathrm{C}(5)$ 安定性： $50{ }^{\circ} \mathrm{C}(6)$ 阻害金属: $\mathrm{Hg} 2+, \mathrm{Ag}+$ 本酵素が産生するサイクロデキストリン（CD）の分析を行ったところ、 $\beta$ - C D が主な 産生物であり、またD-Glucose, D-Galactose, D-Ribose, D-Mannose, D-Arabinose, L-Arabino se,D-Fucose, L-Rhamnoseに転移反応が認められた。次に本酵素の $N$ 末端アミノ酸配列を明 らかにし、他のC G T aseと比較したところ、B.ohbensisのそれと特に高いホモロジ一を 示した。

\section{Bp-12 Brevibacterium 属細菌の生産する $r$ - C G T a s e の性犋 (天野製薬、※大服市工研)}

○森茂治、廣瀬進、大矢隆一、※北畑寿美雄

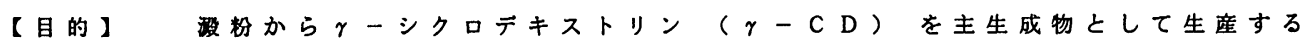

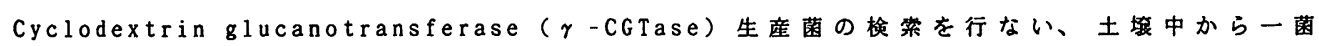
株を得たのて、、の菌と酸菜の性啠について報告する。

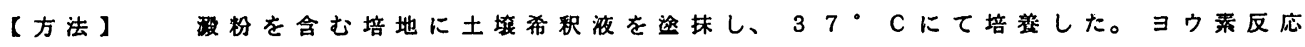

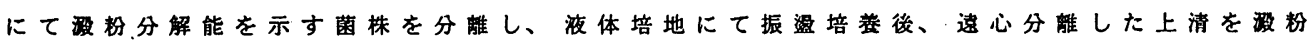
に作用させ、 $\gamma-C$ D を生成した菌株を選定した。C G T a s e 活性の測定はB 1 u e

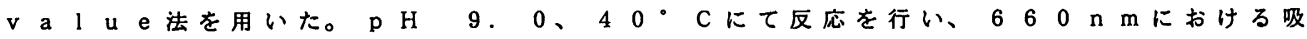
光度を1分間に 1 \% 减少させる醋素を 1 単位とした。反応生成物の分析は薄首ク口マト グラフィ、及び高速液体クロマトグラフィにて行った。

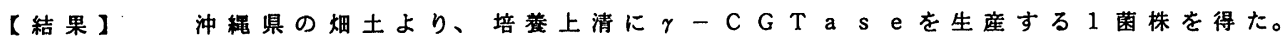
本菌は p H 8 〜 2 にて生育する好アルカリ性の桿菌であり、胞子を作らす、多型性を示 すc。ry ne-form 細菌であり、そのなかても R。d-coc c u s c y c 1 e を示す事から、クラム泩の 本菌は抜粉を岸素源として培巷すると、上清に $\gamma$ - C G T a s e を産生した。除菌後、限 外漏過䐜により浱縮し、種々のカラムクロマトグラフィにて精製を試みた。

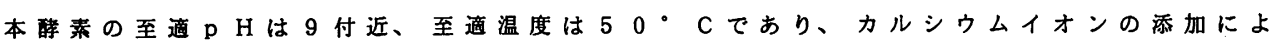

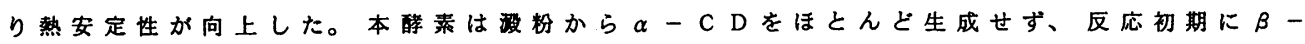
$\mathrm{CD}$ D」も $\gamma-\mathrm{CD}$ を多く生成したか、反応時間を長くするに従い $\beta$ - C D が增加した。 また、基質浱度を高くすると総 C D 量は減少し、 $\beta-C D$ 生成㗐加增加する傾向にあった 
Bp-13 系状菌90-Kのキシラナーゼ系に関する研究（第 1 報） 酵素の生産性および精製法の確立

（静岡大・教育, *日本食品化工）岡田嚴太郎, ○鈴木康浩, *海野剛裕

【目的】近年, セルロース系バイオマスの高度利用に関連して, ヘミセルロース分解醉 素の一種キシラナーゼ(EC 3.2.1.8) が注目されている。我々は最近, 長野県小県郡東部町 にて朽木から採取され, 当研究室で単離・培養された系状菌90-K株をキシランを唯一の孷 素源に用いた液体培地で培養すると, 本菌は大量のキシラナーゼを菌体外に分泌すること を明らかにした。本報では, 当該菌にとり最む効率的な醉菜産生条件および酵素精製法の 確立を目指した。

【方法】500 mlのエルレンマイヤーフラスコを用いて当該菌を液体培養し、醉素の生産 性に影響を与える種々の要因（炭素源の種類・濃度, 培地の $\mathrm{pH}$, 培養温度・日数など）に ついて詳細に検討し, 最適醅素産生条件を確立した。培養後の除菌液を硫酸アンモニゥム で塩析後, 塩析物を各種のカラムクロマトグラフィーにかけることにより, 酵素の精製を 行った。精製工程は全て $4{ }^{\circ} \mathrm{C} の$ 低温室で行われた。

【結果】本菌の効率的な酵素産生条件としては， $0.8 \%(w / v)$ キランを唯一の炭素源に 用いる液体培地に, $3 \sim 4$ 日間前培養した当該菌を植菌し, 初発 $\mathrm{pH} 6.0,25^{\circ} \mathrm{C}$ で11日間振 溵培養 (120 rpm)するのが最適であると判明した。約 $2,000 \mathrm{~m} 1$ の除菌液を固形硫酸アンモ ニゥムで塩析（90\%飽和）後, 塩析物を CM-TOYOPEARL 650Sのカラムにかけると, 大量の 色素タンパク質が除去された。活性画分をプールして, 次のTOYOPEARL HW-55 のゲル濾過 にかけると 2 個の主要な活性画分（Peak I およびII) が分離された。それぞれの活性画分 を再度前記のゲル滤過にかけ，2種のキシラナーゼを分画・単離し，それぞれをキシラナ 一ゼIおよび II と呼称した。

Bp-14 系状菌90-Kのキシラナーゼ系に関する研究（第 2 報）

精製醉素のキャラクタリゼーション・基質特異性・作用機作

（静岡大・教育, *日本食品化工） ○岡田嚴太郎, 鈴木康浩, *海野剛裕

【目的】本報では，前報で述べた精製法を用いて調製された高純度キシラナーゼIおよ び IIについて，それらの示す物理化学的ならびに酵索学的性質を精查・比較すると共に， 両精製酔素の示す基質特異性ならびに作用機作の解析などを目指した。

【方法】精製醉菜標品の力価については，0.25\%可溶性キシラン（0at Spelts）に酵 を $40^{\circ} \mathrm{C}, \mathrm{pH} 5.5$ で作用させ, その際生成される還元糖を Somogyi-Nel son 法を用いて比色 定量し, 1 分間に $1 \mu \mathrm{mol}$ のキシロースに相当する還元力を生成する酵竟を 1 単位とし た。精製酵素の分子量の測定はWeber-Osborn の SDS-PAGE 法によった。反応生成糖の定 性・定量にはPPC, TLC，HPLCなどを適宜用いた。

【結果】キシラナーゼI およびII はいずれむ，Native-PAGEおよびSDS-PAGEで，それぞ れ単一のタンパク質染色バンドを与える高純度標品であった。キシラナーゼ I および II の 分子量はそれぞれ $24,000,22,500$ と推定され，可溶性キシランに対する比活性值はそれぞ れ 143，137 U/mg protein, また不溶性キシランに対するそれは170,156 U/mg protein

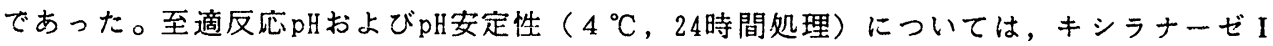
および IIでそれぞれ $5.8 ， 4.8-8.5 ； 5.5 ， 5.2-8.5$ であった。一方, 至適反応温度は両キ

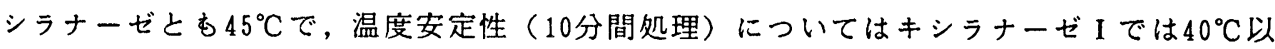
下で，またキシラナーゼПでは $45^{\circ} \mathrm{C}$ 以下でそれぞれ $100 \%$ の残存活性が認められた。両精 製キシラナーゼはいずれあキシラン分子をエンド様式で水解し, 反応生成糖としてキシロ ビオース，キシロトリオースおよびその他のオリゴ糖が検出された。各種基質に対する基 質特異性などを検討した結果についてす報告する。 
Bp-15 土壤より得られたキシラン分解微生物によるキシラン分解醅素の生成と それらの有袎溶媒類存在下における反応

（千葉大・生物生産）○篠山浩文、鈴木正義、角谷順子、藤井貴明

(目的) 我々は微生物の生産する糖質分解䣼素の糖転移反応に関する醉菜学的解析とその 自然界における役割の解明、さらにその検討過程で得られた知見の社会への還元を目的に 研究它准めている。今回は、有用性にとらわれることなくキシラン分解微生物を土壌から 分離し、それらの生産するキシラン分解醉素について、有機溶媒類を反応系に存在させる ことによ中どのような反応パターンが胃られるのかを検討した。

(方法と結果) キシラン分解微生物は各地の土壤からキシラン寒天プレートを使用して、 比較的生青の良好なものを溶解班の大きさに関係なく分離した。分離菌の大部分は系状菌 で、Penicillium 属のものが多かった。さらに、それらをキシラン液体培地で振澺培養後、 培養乃液についてキシロオリゴ糖、キシランを基質として、n-propanol, iso-propanol, tert- -butanol, acetone, phenol 類等を共存させて反応させたところ、いくつかの反応パ ターンが見られた。すなわち、有機溶媒類の存在に関係なく基質の分解は良好でかつ転移 生成物（ $\beta$-.-*キシロシド）が著量蓄積するもの、有機溶媒類の存在で反応性が著しく低下 するもの、キシランに作用し、転移生成物を蓄積するがキシロオリゴ糖にはほとんど作用 しないものなどが見られた。このうち、転移生成物が著量蓄積するものについてはこれま でに我々が報告した $\beta$-キシロシドの醇素的合成法に利用できるものと思われた。 (文献)

H. Sh inoyama et al., Agric. Biol. Chem., 52, 2197 (1988)

H. Shinoyana et a1., Agric. Biol. Chem.., 55, 849 (1991) 